\title{
Detecting Collusion in Timber Auctions: An ApPlication to Romania
}

\author{
JEAN-DANiEl SAPHORES, JeFFrey R. VinCEnt, AND VALy MarochKo \\ WITH IOAN ABRUDAN, LAURA BOURIAUD, AND CLIFFORD ZINNES
}

\section{Correspondence}

\author{
Saphores: $\quad$ School of Social Ecology \\ University of California, Irvine \\ Irvine, CA 92697-7075 \\ saphores@uci.edu \\ Vincent: $\quad$ Graduate School of International Relations \& Pacific Studies \\ University of California, San Diego \\ 9500 Gilman Drive \\ La Jolla, CA 92093-0519 \\ jvincent@ucsd.edu
}

\begin{abstract}
World Bank Policy Research Working Paper 4105, December 2006
The Policy Research Working Paper Series disseminates the findings of work in progress to encourage the exchange of ideas about development issues. An objective of the series is to get the findings out quickly, even if the presentations are less than fully polished. The papers carry the names of the authors and should be cited accordingly. The findings, interpretations, and conclusions expressed in this paper are entirely those of the authors. They do not necessarily represent the view of the World Bank, its Executive Directors, or the countries they represent. Policy Research Working Papers are available online at http://econ.worldbank.org.
\end{abstract}

\section{$\underline{\text { Acknowledgments }}$}

We thank, in alphabetical order, Peter Dewees for guidance and comments on various drafts, Michael Kanaley for administrative support, Nalin Kishor for comments on the draft final report, Liviu Nichiforel for data collection in Suceava, Leonard Padureanu for a background report that provided much of the information in section 3, Robert Subrick for constructing the auction datasets for Neamt and Suceava, and Clare Wolfowitz for editorial assistance. We also thank the individuals and organizations in Romania listed in the appendix for their cooperation, the World Bank and the U.N. Food and Agriculture Organization for financial support, and the University of California's Institute on Global Conflict and Cooperation for administrative support. 


\title{
Detecting Collusion in Timber Auctions: \\ An Application to Romania
}

\begin{abstract}
Romania was one of the first transition countries in Europe to introduce auctions for allocating standing timber (stumpage) in public forests. In comparison with the former system in the country-administrative allocation at set prices-timber auctions offer several potential advantages: greater revenue generation for the government, a higher probability that tracts will be allocated to the firms that value them most highly, and stronger incentives for technological change within industry and efficiency gains in the public sector. Competition is the key to realizing these advantages. Unfortunately, collusion among bidders often limits competition in timber auctions, including in well-established market economies such as the United States. The result is that tracts sell below their fair market value, which undermines the advantages of auctions.

This paper examines the Romanian auction system, with a focus on the use of econometric methods to detect collusion. It begins by describing the historical development of the system and the principal steps in the auction process. It then discusses the qualitative impacts of various economic and institutional factors, including collusion, on winning bids in different regions of the country. This discussion draws on information from a combination of sources, including unstructured interviews conducted with government officials and company representatives during 2003. Next, the paper summarizes key findings from the broader research literature on auctions, with an emphasis on empirical studies that have developed econometric methods for detecting collusion. It then presents an application of such methods to timber auction data from two forest directorates in Romania, Neamt and Suceava. This application confirms that data from Romanian timber auctions can be used to determine the likelihood of collusion, and it suggests that collusion reduced winning bids in Suceava in 2002 and perhaps also in Neamt. The paper concludes with a discussion of actions that the government can take to reduce the incidence of collusion and minimize its impacts on auction outcomes.
\end{abstract}




\section{Detecting Collusion in Timber Auctions: \\ An Application to Romania}

\section{Introduction}

Romania was one of the first transition countries in Europe to introduce auctions for allocating harvesting rights for standing timber (stumpage) in public forests. The auctions involve small tracts of forestland that must be harvested within a short period, typically less than a year from the date of the sale. From this standpoint, the Romanian system is roughly similar to the system used in U.S. national forests. ${ }^{1}$

In comparison with the former system in the country - administrative allocation of timber at set prices-timber auctions offer several important advantages in principle. From the standpoint of the government, the most obvious one is that auctions are likely to generate more revenues; in Romania; this was undoubtedly a primary impetus for introducing auctions. But auction systems also have other potential advantages that may be more subtle but are arguably more important. One is static efficiency in the forest sector: with auctions, tracts are more likely to be allocated to the firms that value them the most. A second is dynamic efficiency: auctions are better at creating incentives for technological change, which is the ultimate engine of cost reductions in timber harvesting and wood processing; it will eventually allow firms to bid higher amounts. A third is efficiency within the public sector. Auctions for timber in Romanian state forests are administered by the National Forestry Administration (NFA). This is a financially autonomous agency which, in addition to administering auctions, has responsibilities related to forest management, regulation, and extension. It has 37 regional forest directorates (directia silvica). Firms are allowed to participate in timber auctions in any forest directorate. This choice creates an incentive for directorates to attract buyers by reducing bureaucratic hassles as well as other pecuniary and nonpecuniary costs of doing business.

As this last point implies, competition is the key to the realization of the advantages of

\footnotetext{
${ }^{1}$ It differs, however, from auction systems recently introduced in some other countries that are trying to create a more market-based forest sector. An example is Cameroon, where auctions are being used to allocate long-term (15-year, renewable once) timber concessions that cover large areas of forest.
} 
auction systems. Unfortunately competition is often limited in timber auctions for a variety of reasons. One that has attracted regular attention in the United States since the 1960s is collusion (Mead 1967, Johnson 1979, Brannman 1996, Baldwin et al. 1997). ${ }^{2}$ Collusion is a coalition of bidders who try to circumvent competition in order to obtain timber at a lower cost. Such agreements are usually illegal, but detecting them can be difficult. If collusion is a problem with timber auctions in the United States, an advanced market economy with well-developed legal institutions, it is likely to also be a problem in transition economies like Romania. A previous econometric study on auctions in the Suceava forest directorate found evidence that winning bids were significantly lower for tracts with fewer bidders (HIID 1996). Although this is by no means proof that bidders were colluding on those tracts, ${ }^{3}$ it does indicate the important role of competition in determining the prices the NFA receives.

This paper examines the Romanian auction system, and uses econometric methods to detect collusion. The first and second sections describe the historical development of the system and the main steps in the auction process. The third section describes the impact of economic and institutional factors on winning bids in different regions of the country; it includes a brief review of evidence on collusion. Information in these first three sections comes from a combination of sources, including unstructured interviews conducted with government officials, company representatives, and NGOs during 2003. Individuals interviewed are listed in the appendix. The fourth section summarizes some key findings from the research literature on auctions, with an emphasis on empirical studies that developed econometric methods for detecting collusion. The fifth section presents an application of such methods to recent timber auction data from two Romanian forest directorates, Neamt and Suceava. Our results confirms that data from Romanian timber auctions can be used to determine the likelihood of collusion, and it suggests that collusion reduced winning bids in Suceava in 2002 and perhaps also in Neamt, where less data were available. The sixth section concludes this paper.

\footnotetext{
${ }^{2}$ We review these studies in section 4.

${ }^{3}$ For example, tracts that sell for low prices might have few bidders not because of collusion but rather because they are of low quality. To control for this endogeneity between the quality of a tract and the number of bidders, Vincent (1996) used the predicted number of bidders rather than the actual number in a re-analysis of the data. He found less evidence of an impact of bidder number on winning prices.
} 


\section{Development of the timber auction system in Romania}

During the Communist era, each county in Romania had a single timber seller, which was the local NFA branch, and a single timber buyer, a state-owned forestry enterprise. The former sold timber to the latter at prices set by the government. This situation remained relatively unchanged for the first two years after Ceausescu was deposed. Then, in response to the emergence of private enterprises in the forest sector and financial pressure, the NFA branch in Neamt decided to experiment with auctions as a means of allocating standing timber to this new user group. The NFA headquarters subsequently approved the use of auctions and encouraged other branches to use them. Soon after, the government issued Ministerial Order 572 (1991), which mandated auctions for selling timber to private enterprises. It did not, however, provide guidelines to implement auctions. Each NFA branch introduced auctions at its own pace with its own rules.

Government Decision 342 (1995) represented an initial attempt to create a consistent and comprehensive legal basis for the auction system. Among other things, it extended the auction requirement to include timber sales to state-owned enterprises. The Government had observed that winning bids in auctions organized for private firms exceeded by a large margin the administered prices paid by state-owned enterprises. Government Decision 695 (1998) brought additional clarity and uniformity to the auction system. It mandated auctions in all public forests, including the ones under the jurisdiction of local councils and not the NFA. It authorized, but did not require, the NFA to administer auctions in non-NFA forests, including private forests. $^{4}$

In addition to Government Decision 659, the current legal framework for timber auctions includes Governmental Regulation 96 (1998) concerning the management and administration of forests, together with the Forest Code. It also includes several detailed governmental and ministerial regulations covering auction procedures, logging technologies and techniques, monitoring and enforcement of logging operations (tree marking, legal documents for harvested

\footnotetext{
${ }^{4}$ In early 2004, Government Regulation 85 (2004) introduced new rules that require timber from forests controlled by local councils to be included in the NFA auctions. It also included provisions to improve the advertising of upcoming auctions and the accounting of logging companies' harvest quotas. See sections 2.5 and 2.6.
} 
timber, control of timber flows during harvesting), and harvest contracts (payments for timber harvested, payment and reimbursement of bid guarantees, resolution of disputes). ${ }^{5}$

Relatively few modifications have been made to the framework laws and regulations in the last five years, with the exception of regulations dealing with harvest contracts, which have changed at least once a year. Ministerial Order 635 (2002) contains the main body of current contract regulations. One important modification is NFA Order 6465 (October, 2001), which mandated sealed bidding instead of oral auctions and prohibited sales of timber by negotiation. The former mandate was quickly cancelled, but the latter prohibition remains in place. Another important modification is Law No. 654 (2002), which authorizes long-term timber sales. We discuss the motivation for this new law, and early experience with it, in Section 3.

\section{Steps in the timber auction process}

In this section we describe the main steps in the timber auction process, in the approximate order in which they occur.

\subsection{Annual allowable cut}

The process of selling timber starts with the determination of the annual allowable cut (AAC), which is the maximum volume of timber that may be harvested in a given year. The building blocks for the AAC are forest production units. These are relatively homogeneous areas of forestland that are intended to produce a sustained and even flow of timber over time. Each production unit is intended to eventually contain equal areas of each forest age class (a "normal forest"). Every ten years, the National Institute for Forestry Research and Management Planning (generally known by its Romanian acronym, ICAS), an autonomous unit within the NFA, prepares management plans for the production units. ${ }^{6}$ These plans are reviewed by the Forest

\footnotetext{
${ }^{5}$ Governmental Regulation 96 (1998) was recently modified by Law No. 120 (2004), which mainly concerns private forest administration and the enforcement of existing rules and regulations.

${ }^{6} \mathrm{~A}$ few dozen private firms have begun preparing management plans in the past few years. Most operate in cooperation with ICAS instead of competing with it.
} 
and Wildlife Territorial Inspectorates in the National Authority for Control. ${ }^{7}$ They contain proposed annual harvest schedules for the production units over the ten-year period. These harvest schedules are intended to ensure that harvests are in balance with timber growth. During the last two decades, ICAS has proposed an aggregate annual harvest below the estimated aggregate annual growth, to offset harvests that exceeded scheduled amounts in earlier periods.

Each year, a top-down process is used to allocate the aggregate scheduled harvest across regions of the country, categories of forest owners (the state, local councils, private parties, etc.), and categories of forest users. This process establishes the actual AAC. There are three main categories of users: "economic agents" (i.e., timber harvesting and wood processing firms), the rural population, and the NFA itself. Two subcategories have been added to the economic agents category since 2001: users who harvest for the needs of the National Construction Agency, and users who have won long-term contracts. Before auctions, the NFA and holders of long-term contracts select tracts to fill their user shares. The remaining tracts enter the auctions.

The allocation of the AAC across regions and owner and user categories is significantly a political act. It is proposed by the Ministry of Agriculture, Forests, Water, and Environment ${ }^{8}$ and must be approved by a parliamentary committee and signed by the Prime Minister. Although different user groups understandably lobby to influence the allocation in their favor, we found little evidence to suggest that corruption affects the allocation process.

\subsection{Harvest scheduling and auction timing}

At the level of forest production units, the AAC is implemented through the harvest schedule, which indicates which tracts should be harvested in each year during the current decade. Tract selection is driven largely by consideration of factors that affect long-run forest health, in particular forest regeneration and forest protection. Natural catastrophes, such as windstorms, forest diseases, and pest outbreaks, affect the actual implementation of the harvest schedule. The removal of damaged timber is given higher priority than the harvesting of tracts on the original

\footnotetext{
${ }^{7}$ Before June 2003, the Inspectorates were in the Ministry of Agriculture, Forests, Waters, and Environment. They also review forest management plans prepared by private firms.

${ }^{8}$ Since March 2004, the ministry has been reconfigured as the Ministry of Agriculture, Forests and Rural Development.
} 
schedule, and when such salvage logging occurs, the harvest date for some of the tracts on the original schedule is postponed to ensure that the AAC is not exceeded.

Forest directorates organize two primary auctions each year. The first is in the spring, traditionally between March $1^{\text {st }}$ and April $15^{\text {th }}$, when 40 percent of the AAC for the current year is sold. The second is in the autumn, traditionally between August $1^{\text {st }}$ and September $15^{\text {th }}$, when 20 percent of the AAC for the current year and 40 percent of the AAC for the following year is sold. Forest directorates can also organize secondary auctions for tracts that do not sell at the primary auctions or for emergency cuttings. The managers of administrative subunits of the forest directorates, which are termed forest divisions (ocolul silvic), ${ }^{9}$ have a lot of latitude in allocating tracts between the spring and fall auctions. NFA managers and staff at the forest division level also decide the quantity of timber offered at secondary auctions as well as the timing of those auctions.

\subsection{Tree marking and timber inventory}

The selection of trees to be harvested within a tract depends on the silvicultural treatment applied (e.g., final harvest or thinning). Trees to be harvested are marked individually with a special forest hammer. An exception is made for clear cuts: in that case, the tract boundaries are simply marked in the field. Trees are inventoried one by one, with information collected on species, trunk diameter 1.3 meters above the ground, and timber quality. Each tree is given a serial number, which is painted on the trunk. Tree heights are measured for a sample of marked trees.

Information from the inventory is recorded on the tract evaluation form (act de punere in valoare, or APV). The NFA guarantees the timber volume reported on the APV to be accurate within 5 percent. ${ }^{10}$ The APV constitutes the basis for timber transactions, because it identifies the quantity and the quality of timber to be sold. The APV also plays an essential role in law enforcement, because it provides proof that timber can be legally harvested. Each APV is given a unique identifying number.

\footnotetext{
${ }^{9}$ The boundaries of forest divisions do not necessary coincide with the boundaries of forest production units.

${ }^{10}$ Winning bidders have a limited time in which to dispute the NFA's volume estimates and must incur what can be considerable forest inventory costs in order to make their case.
} 


\section{4. $\quad$ Reserve prices}

The government's reserve price, specified on the APV, is one of the few pieces of economic information provided on the APV. It provides the starting point for bidding and is expressed in lei per cubic meter, averaged across the total timber volume in a tract. When the government issued the first comprehensive regulations for timber auctions in 1995, it declared that reserve prices must be approved by the Ministry of Finance. In 1997 it removed reserve prices from the list of state-approved prices and authorized the NFA to set reserve prices independently, guided by two principles: covering the costs of forest administration, and setting a higher price for better quality and more accessible timber. In April 2001, however, the government brought reserve prices back under state supervision; currently, the NFA must submit proposed reserve prices to the Competition Office for review. The reserve prices approved by the Competition Office must be used in all auctions for public timber, though not in auctions for timber in private forests.

Reserve prices are one of the most important tools that governments have to fight collusion and ensure that the timber sold in auctions fetches a fair market price. Unfortunately, the most thorough previous study on timber auctions in Romania, which analyzed 1992-95 data from auctions in Suceava, concluded that "current starting [i.e., reserve] prices are far below market values and inadequately reflect variations in market values, thus raising the risk that the government is not receiving as much revenue as it could and reducing the ability of stumpage prices to stimulate more efficient wood-based industries" (HIID 1996, p. 3). This is a result of basing reserve prices on forest administration costs instead of on data related to the market value of timber. We return to this point in the concluding section.

\subsection{Marketing}

Forest directorates are required to publish announcements of auctions at least 30 days before the auction date in two newspapers, one of which must be local. Most directorates also publicize auctions on the Internet. Several forest directorates - in particular, Arad, Ialomita, Mures, and Timis - have aggressively implemented measures to attract more firms to participate in their auctions. Examples include publicizing auctions a year in advance, promoting lesser-known timber varieties, and meeting with representatives of harvesting firms to better understand their needs. The Tomnatec forest division in Suceava, which until recently was managed by ICAS, 
has been a pioneer in using direct marketing methods to publicize its auctions. ${ }^{11}$ It faxes invitations to firms and follows up with phone calls.

Interested firms are allowed to review the APV for each tract before an auction. They are also allowed to review a separate document that describes all the rules for harvesting the tract as well as the deadline for signing the timber harvest contract by the winning bidder.

\subsection{Qualification and registration of bidders and bid guarantee}

Five days before an auction, the forest directorate decides which firms are qualified to participate. There are four main qualification criteria: the firm must be legally constituted; it must have timber harvesting as an economic activity; it must not have outstanding debts to the forest directorate organizing the auction or to other forest directorates; and it must not have exceeded its authorized timber harvest quota for the current year.

The fourth criterion requires additional explanation. In 1995, as part of Government Decision 695, the Government created a committee to determine the annual harvesting capacity of individual companies in the forest sector. The committee has 9 members: 4 with expertise in forest management, 4 with expertise in timber harvesting, and 1 with expertise in wood processing. It reviews a company's technical capabilities, financial status, and human resources and, on this basis, determines the total annual amount of timber that the company is authorized to harvest. The NFA allows a company to participate in an auction only if the amount of timber the company already has under contract is less than the company's annual quota. The NFA is reportedly diligent in enforcing this rule.

Firms that qualify to participate in an auction must register in advance for the individual tracts they intend to bid on. For each such tract, they must pay the NFA a deposit, or bid guarantee, which is equal to 5 or $10 \%$ of the estimated minimum value of a tract (= reserve price times timber volume), depending on the size of the tract. The deposit is intended to discourage frivolous bidding. The NFA returns the deposits to losing bidders within 3 days of the auction.

\footnotetext{
${ }^{11}$ It was transferred to NFA administration due to alleged mismanagement.
} 


\subsection{Bidding procedure}

The NFA has experimented with both oral and sealed auctions. Until 2001, it used mainly oral auctions. As noted earlier, in October of that year it prohibited oral auctions. Although this prohibition was quickly cancelled, since January-February 2002 some forest directorates have organized only sealed-bid auctions. ${ }^{12}$

A sale is considered final only when there are at least two registered bidders and at least one of them offers the reserve price. Tracts that fail to sell at the primary auction are then proposed for sale at a secondary auction, which is typically scheduled within a few weeks of the original auction. Until recently, the forest directorate was allowed to sell any tracts still unsold after the second auction by negotiating with the last firms that expressed interest in them. A verbal order of the NFA chief executive, issued in early 2003, prohibited such negotiated sales.

\subsection{Timber harvest contract and harvest warranty}

The high bidder must sign a timber harvest contract within 10 working days after the auction or lose its bid guarantee. After signing, it must pay the NFA a deposit of 5 percent of the auction value (= winning bid times timber volume) before it begins harvesting. This harvest warranty is intended to discourage logging damage. The NFA returns the warranty at the end of the harvesting operation if the remaining stand is not damaged.

\subsection{Differences across forest directorates}

Some of the procedures described above can differ across forest directorates. They include:

- The rules for accepting the APV. In Neamt, firms cannot claim any adjustment for discrepancies between estimated and actual timber volumes once harvesting has begun. In Suceava, firms can request a re-evaluation of timber volumes (and qualities) up until the halfway point of the period scheduled for harvesting the tract.

- The wording of harvest contracts, in particular rules related to breach of contract and litigation.

- The possibility of negotiating deadlines related to the harvest contract.

- The scheduling of payments.

\footnotetext{
${ }^{12}$ There is just a single round of bidding in the sealed-bid auctions.
} 


\section{Effects of economic and institutional factors on bids in Romanian timber auctions}

Bids in timber auctions are affected by both the physical characteristics of tracts, such as the amounts and qualities of timber they contain or their terrain, broader economic and institutional factors. The effects of physical characteristics are straightforward: for example, tracts with more timber of higher quality tend to attract higher bids, while tracts with more difficult terrain tend to attract lower bids. Differences in physical characteristics have been found to be important in explaining bid variations across tracts in Romania (HIID 1996, Vincent 1996).

In this section, we focus instead on the effects of various economic and institutional factors, especially the ones that affect the degree of competition in timber auctions. These factors can affect multiple auctions or multiple tracts within the same auction; they are more "macro" than the "micro" characteristics of individual tracts. We begin with basic supply and demand considerations and close with factors related to corruption and collusion. Our main purpose is to understand the impact of these factors on the winning bids in timber auctions, in order to provide a basis for formulating our econometric models and interpreting our results.

\subsection{Regional timber markets within Romania}

Geographical differences in forest composition, terrain, infrastructure, and other factors have led to the development of several fairly distinct timber markets in Romania. These markets are by no means autarkic - for example, officials in the Timis forest directorate tell of a wood processing company from a town $400 \mathrm{~km}$ east that regularly purchases timber in the directorate's auctions - but the differences are sufficiently great to produce persistent differences in the level of winning bids. The very fact that winning bids vary across the regions suggests that timber markets are functioning in the basic sense of reflecting differences in supply and demand forces.

Table 1 shows data on scheduled sales of mature timber at auctions held during the first 7 months of 2003 in each forest directorate. Volumes are totals for the 7-month period, and winning bids are weighted-average means (i.e., total sales values divided by total volumes sold). "Mixed hardwoods" and "mixed softwoods" both refer to miscellaneous species in the broadleaved tree group. Mean winning bids that are below the national mean for a particular timber group and directorate are shown in italics. The data in this table indicate that the directorates 
vary greatly in terms of the amounts and types of timber sold by auction and the mean winning bids for that timber. Suceava stands out as a directorate that sells a large volume of mature timber, overwhelmingly coniferous, followed by Neamt. Bacau and Caras Severin are major sellers of nonconiferous timber. Winning bids tend to be highest in directorates in the East, Northwest/West, and South regions, and lowest in the Central, Danube, and Southwest regions.

Based on this table and other sources of information, we can describe the regional timber markets in the country as follows. The most timber-rich regions are the Northeast, Northwest/West, East, and Southwest. The Northeast is the largest supply source for coniferous species such as pine, fir, and spruce. It has a well-established industry with large capacity in both timber harvesting and wood processing.

Nonconiferous species are more important in the Northwest/West and East (oak and cherry) and Southwest (beech). Among these three regions, demand tends to be greater in the Northwest/West, due to high export demand from neighboring western countries. As a consequence, winning bids have tended to be higher than in the East. ${ }^{13}$ Demand in the Southwest, which includes only the Caras Severin forest directorate, is very weak despite the good quality of the region's beech stands. This region is lightly populated and has high wage rates, due to a large mining industry and commercial trading opportunities with neighboring Serbia. The tight labor market has discouraged the development of local timber harvesting and wood processing industries.

The Central region and the South have strong demand but poor supply. Factories in these regions rely on timber harvested elsewhere. The Central region has the biggest investment in wood processing in Romania, but it also has the smallest area of public forest in the country, and forest ownership is divided among numerous small owners due to restitution. This depresses demand for timber from local sources because mills prefer to deal with large, stable suppliers.

The Danube region (counties of Bucuresti, Constanta, Dolj, Ialomita, Mehedinti, Olt, Tulcea) is a special case. It has a substantial supply of poplar trees. There is some export demand for poplar wood, but it is not consistent. There is also some domestic demand by the

\footnotetext{
${ }^{13}$ This was not the case during the first 7 months of 2003, however: winning bids were fairly consistently higher in the East than in the Northwest/West.
} 
pulp and paper industry. However, Law No. 570 (2003), adopted in late 2003, prohibits timber harvests for 3 years in much of this region and parts of the South. The stated reason is to fight desertification.

\subsection{Factors on the supply side}

\subsubsection{Number of timber sellers}

The NFA manages timber supply from state forests in Romania. These forests currently account for about three-quarters of the country's forest area, but this proportion is declining due to restitution. Nevertheless, the NFA remains the leader in the wood market in Romania. It sells about four-fifths of the total volume of timber harvested in the country, and its supply decisions have a strong influence on timber prices. Its ability to supply large timber volumes on a regular basis makes it the preferred timber source for large firms.

Local councils administer just above 10 percent of the total forest area, approximately 750,000 hectares. Of this amount, about 400,000 hectares are managed by the NFA on a contract basis. Local councils sell standing timber by auction, using the same reserve prices as the NFA. Timber from local council forests managed by the NFA is sold in the same auctions as timber from the NFA's own forests (i.e., state forests). The amount of timber offered by local councils is reportedly large enough in some locations to depress the winning bids in NFA auctions by a significant amount. Local councils tend to put strong pressure on the Ministry to authorize a larger AAC. They have chronically low budgets, and their primary forest management objective is revenue generation.

Individual private owners administer approximately another 10 percent of the total forest area. They have differing management objectives. Most, like the local councils, have a strong interest in short-term income. Others, however, would like to preserve the forest for a future time when they expect to need wood for building houses, etc. Private owners are not required to sell timber by auction, nor are they required to use the official reserve prices if they do (unless the NFA administers the auctions on their behalf). At present, any influence they have on timber markets tends to be very local and ephemeral.

Owner associations administer forests in the eastern Carpathian Mountains. These associations trace back to common property forests that the Austrian Empire granted to local 
communities in return for guarding its borders. Like private owners, the associations are not required to sell timber by auction. They have a strong revenue motive and can consistently influence prices in local markets.

Churches (including monasteries) comprise the final category of timber sellers. Their properties are individually small, 30 hectares each, and are spread all over the country. The total area of their properties can be sizeable in counties with many churches, though still much less than before the communist rule. For example, an estimated 15,000 hectares will be restored to churches in Suceava $(14,000$ hectares have already been restored), compared to the nearly 200,000 hectares owned by them previously. The churches' main forest management objective is to produce raw material for new buildings or restoration of existing ones. They tend to use most of the timber they harvest. Their influence on the market is not significant in most forest directorates except at a very local level.

\subsubsection{Annual allowable cut}

The NFA and local councils are inelastic supply sources, owing to the determination of timber harvests on the basis of AAC calculations instead of timber market conditions. The effect, well known to forest economists, is to exacerbate the volatility of timber prices over the course of the business cycle (Waggener 1969). When markets are strong, mills are starved for timber and bid up prices to levels that can lead to widespread bankruptcies if markets cool off too rapidly. ${ }^{14}$ Conversely, when market conditions are weak, as they have been in Romania during much of the post-communist period, the result is low bids: supply is too high relative to demand. Some tracts might go unsold simply because they are put on the market at the wrong time, not because they are inherently undesirable.

To a certain extent, timber prices have been inadvertently supported by the policy of setting scheduled harvests below growth and, since the early 2000s, by the failure of the Ministry to set annual harvest quotas on time. ${ }^{15}$ Some auctions have been postponed or cancelled due to the latter factor. Large salvage sales have partially offset this factor in some directorates (e.g., Neamt in 2002). Moreover, it is not clear that the policy to reduce scheduled harvests has been

\footnotetext{
${ }^{14}$ As happened in the U.S. in the early 1980s. See Mattey (1990).

${ }^{15}$ The Ministry did set the quota for 2005 on time.
} 
followed in practice: the share of forestland in the $0-20$ year age class, approximately 22 percent, remains significantly larger than the share for any of the other five 20-year age classes (20-40, 40-60, 60-80, 80-100, 100+), even though communist rule ended 14 years ago.

Planning by forest users-determining where the AAC is likely to bind and where it is likely to make surplus timber available, and making wood-processing investments accordinglyis difficult because ICAS's forest management plans are not publicly available. Potential bidders do not learn about a tract's availability until an auction is advertised. This lack of information can also be expected to contribute to increased price volatility, because milling capacity is less likely to be in line with the supplies actually made available.

\subsubsection{Physical access to timber}

A limited and poorly maintained road network increases the costs of forest access and thus depresses bids in timber auctions. According to a report prepared for the World Bank by Environmental Resources Management, ${ }^{16}$ Romania's road network includes 32,500 km of forest roads, 7,600 km of public roads in or near forests that can be used for logging operations, and $1,450 \mathrm{~km}$ of roads that were constructed for other purposes, such as mining, but can be used for logging. ${ }^{17}$ This network provides access to only 65 percent of Romania's production forests. Its density, at $6.1 \mathrm{~m} / \mathrm{ha}$, is much less than in other European countries with mountainous forests. For example, Austria, France, Germany, and Switzerland all have $25-45 \mathrm{~m} / \mathrm{ha}$ of roads in regions with timber producing forests.

Most of the forest roads in Romania were constructed before 1985. They became the responsibility of the NFA in 1994. Although the NFA has constructed more than $300 \mathrm{~km}$ of forest roads and rehabilitated nearly $300 \mathrm{~km}$, some 7,000 km have become unusable due to deterioration and inadequate maintenance. Effective access is thus even less than the figures in the previous paragraph would indicate.

\footnotetext{
${ }^{16}$ Environmental Assessment Update, Volume I: Summary and Main Report (September 2002), prepared for the Romania Forest Development Project.

${ }^{17}$ There are also $65 \mathrm{~km}$ of forest railroads.
} 


\subsection{Factors on the demand side}

\subsubsection{Number of timber buyers}

Only domestic firms are permitted to participate in the NFA's auctions for standing timber. Winning firms are not allowed to resell tracts to other firms, domestic or foreign. The NFA formerly organized a separate set of auctions for harvested logs — not standing timber - that were open to foreign firms, but it suspended them following strong lobbying by domestic wood processors. Foreign demand thus influences Romanian stumpage prices only indirectly, through derived demand resulting from exports of sawn wood and other processed products. Though indirect, this influence is significant. Economic conditions in the Middle East, which is the traditional import leader for Romanian sawn wood, are particularly influential. The stumpage price for beech fell after Middle Eastern demand for steamed beech sawn wood fell. Economic conditions in Western Europe are becoming more influential. Exports to the west have increased recently due to Western European investments in the wood processing industry.

Domestic timber buyers fall into two categories. The first includes free-standing logging companies that purchase standing timber and sell the harvested logs to wood processing companies. According to a report by WWF, ${ }^{18}$ the original single, state-owned logging company split into three regional companies in 1993. By 1994, these had split into 17 companies with majority state ownership. By 1996, they had split again into 32 companies. The state remained the major shareholder, but the proportion of private shareholders increased. This trend of rising private ownership has continued. In addition to the splitting and privatization of former stateowned companies, around 1,000 small private logging companies emerged during the 1990s. Many have since gone bankrupt and ceased operating. Around 600-700 remained as of 1999.

The second category includes companies that process wood. According to the National Institute of Statistics, in 2002 there were 8,634 commercial enterprises in the wood-processing sector (including furniture and pulp \& paper), of which 271 were classified as large (more than 250 employees). Most of the large firms have mixed state/private ownership. Of the remaining enterprises, 1,589 were classified as medium (100-250 employees) and 6,774 as small (less than

\footnotetext{
${ }^{18}$ Technical report on the implementation of the "Certified Forest Products Trade Analysis and Facilitation" Project in the countries of Slovakia and Romania, prepared by the WWF-Danube Carpathian Programme for the Global Forest and Trade Initiative (undated, but evidently mid-2000).
} 
100 employees). ${ }^{19}$ Most of the small and medium firms are privately owned. ${ }^{20}$ The small enterprises are mainly primary processors—sawmills, veneer mills, plywood mills—while most of the medium and large ones go further downstream and make furniture, parquet, etc.

Some of the wood-processing firms are vertically integrated upstream and have their own logging crews. According to the same source, ${ }^{21}$ in 2002 there were 2,246 companies engaged in timber harvesting in the country, including 43 territorial units of the NFA. Of these, 1,939 were limited liability companies, which correspond to small and medium firms, while 81 were joint stock companies, which correspond to large firms. Sixty-one percent of the 1,692 companies that completed the government's annual questionnaire stated that they processed wood in addition to harvesting it. Sawmills are especially likely to have their own logging crews, and large sawmills are especially aggressive in seeking cheap raw material. They use their ability to buy large amounts on a regular basis to convince individual private owners and forest associations to sell standing timber to them outside the auction system and at attractive prices.

There is thus a large pool of timber buyers in the country, albeit one that is relatively shallow in terms of larger companies. In the absence of local monopsonies or collusion (see section 3.4.2 below), this large pool should lead to highly competitive auctions. One potential entry barrier is the central commission that authorizes firms' harvesting capacities, but this barrier is porous. The commission's evaluation is based on documents provided by firms. The commission does not check the actual equipment and other resources that firms claim to own or have access to for harvesting. This creates an incentive for firms to exaggerate their harvesting capacity in order to receive a larger authorization and thus qualify to buy more timber.

\footnotetext{
${ }^{19}$ There were no small- or medium-scale wood-processing companies (including pulp and paper and furniture) before 1990, when the existing 244 large companies in the country were split to improve their management and to make them more attractive for privatization.

${ }^{20}$ Some churches also operate mills as a money-making venture (not just to produce lumber for their own use).

21 “Ancheta statistica privind volumul exploatat de catre agentii economici atestati si suprafata parcursa cu taieri in anul 2002.” Bucuresti, 22 p.
} 


\subsubsection{Technology}

Technologies continue to be outdated and production processes inefficient for many firms in the Romanian forest sector. This is especially true for timber harvesting companies. Inefficient technologies reduce the amount firms can pay for a cubic meter of standing timber.

The small size of the tracts auctioned by the NFA has been identified as one obstacle to more rapid technological change in the sector. A single tract is sufficient to supply a company for only a short period. Even if a company succeeds in purchasing many tracts at one auction, it must harvest them all within a half-year or so. The resulting lack of resource security reportedly diminishes the incentive to invest in improved harvesting and processing equipment.

In response to this situation, in 2002 the Government issued Law No. 71 (operational in 2003): it authorizes auctions for 10 -year timber supplies, but only firms with wood-processing facilities are allowed to participate. Initial experience has been disappointing as none of the large foreign investors in the Romanian wood-processing sector (e.g., Ambro, Fratti or Schweighoffer) has participated so far. ${ }^{22}$ They had evidently no interested in forming long-term partnerships with Romanian firms in order to qualify to bid on the sales. This is discouraging because foreign investors have been primarily responsible for the limited technological change that occurred in the sector, such as the capability to process small diameter logs.

\subsection{Corruption and collusion}

\subsubsection{Corruption}

Quantitative measures of the amount of corruption in Romanian timber markets do not exist. Allegations of corruption come mainly from logging companies. They fall into two categories, bribery and fraud. Companies claim that NFA officers have sometimes demanded bribes in return for approving one or more of the numerous requirements that firms must satisfy to

\footnotetext{
${ }^{22}$ One million cubic meters were offered for sale in 2002. Although 60 companies registered, they bought only 200,000 cubic meters. A smaller amount of timber, 800,000 cubic meters, was offered in 2003. Although nearly all of it sold, there were fewer bidders than in 2002, and they did not bid vigorously. Most of the contracts sold for just two bidding steps above the reserve price. Demand remained weak in 2004, when 400,000 cubic meters was offered. This Information is drawn from editorials posted on the website, forestry.ro.
} 
participate in auctions or to harvest the timber they have purchased. ${ }^{23}$ These claims appear to be more common in regions where firms are small and have few alternative sources of timber. When we asked a representative of one firm what would happen if he refused to pay bribes, he answered that he would never refuse, because forest officers wield too much discretionary power: they determine which roads to repair, thus affecting the firm's access its tracts; which tracts to guard, thus protecting the firm's timber and logging equipment from theft; and what penalties to assess in case of timber harvesting delays or logging damage, thus determining the amount of the harvest warranty returned to the firm.

The second alleged form of corruption involves NFA officers selling timber outside the auction system. One story we were told is that an NFA forester might mark some trees only at the base of the trunk and then cover the marks with leaves and branches, thus causing the trees not to be recorded on the APV as part of the sale. The forester can then sell this unrecorded timber to the firm that wins the tract and pocket the payment himself.

To the extent they exist, these two forms of corruption can be expected to have opposite impacts on firms' bidding behavior. If firms expect that they will need to pay bribes in order to obtain necessary approvals, then they will place lower bids. On the other hand, if firms expect that they will be able to harvest more timber than the APV indicates is present in a tract, then they may place bids that appear unusually high. Information on corruption in the sector is too anecdotal to speculate on which impact is likely to dominate.

\subsubsection{Collusion}

Romania's history of having one large state-owned harvesting enterprise in each forest directorate, combined with the slow emergence of large privately-owned new enterprises, has resulted in the domination of timber markets by one or a few large firms in most forest directorates. A substantial portion of the national harvest is made by just three companies, Forestar, Euroforest, and Romanel. In some directorates, dominant firms reportedly avoid competing with each other by dividing the directorate into regions of influence where they act as local monopsonies. This can be expected to result in excessively low winning bids.

\footnotetext{
${ }^{23}$ Bribes are reportedly often paid in kind (a truckload of logs) instead of in cash.
} 
The opposite, excessively high bids, can occur if dominant firms engage in preclusive bidding to defend their turf. This reportedly has also occurred. Because large companies buy many tracts, their average purchase price is not significantly affected if they overbid on a few tracts in order to prevent other companies from winning. ${ }^{24}$ An extreme example occurred in 1999, when one large company essentially prevented an auction from occurring. Few other firms even dared to enter the auction hall. The company intimidated those who did by placing opening bids two to three times greater than the reserve price.

If collusion is occurring in Romanian timber auctions, then the former effectexcessively low winning bids - should be more common than the latter. Dominant firms can be expected to use preclusive bidding sparingly, to avoid dissipating the benefits of collusion. If the costs of excluding competitors or enforcing a cartel are too high, then it does not pay to collude. For these reasons, our econometric analysis of collusion in Romanian timber auctions focuses on detecting excessively low winning bids. In view of the points discussed in sections 3.1-3.3, this analysis obviously must control for other factors that influence the level of winning bids. Before providing more detail on our analysis, we consider methods that other researchers have applied to detect collusion. Our analysis uses similar methods.

\section{Previous research on collusion}

Interest in methods for detecting collusion has increased during the past twenty years, in tandem with a rising interest in using auctions to allocate a broad range of resources from the public to the private sector. Several recent papers in the research literature have employed econometric approaches to detect collusion. In this section, we summarize some of the main findings from this literature.

At the outset, it is important to emphasize that there is no universal strategy for detecting collusion using auction data (Hendricks and Porter 1989). Instead, institutions, market characteristics, and bidder heterogeneity need to be taken into account in tailored ways in empirical studies. Most of the empirical studies have relied only loosely on auction theory in

\footnotetext{
${ }^{24}$ Some small companies say they are "slaves" of larger companies, unable to compete within them in the auctions and dependent on their trading chains. On the other hand, some large companies complain about unfair competition from small companies, which they claim evade taxes and thus can afford to bid more for timber.
} 
determining how to deal with these complexities. In part this is because the theory of collusion in auction markets is surprisingly recent. ${ }^{25}$ Even today, most of the theory pertains to simple, one-time auctions in which just a single item is offered for sale. A well-developed theory of collusion in repeated auctions in which multiple items are offered for sale - that is, a theory that matches two of the basic characteristics of timber auctions - does not yet exist.

\section{1. $\quad$ Early studies on collusion in timber auctions}

Timber auctions have been a recurrent focus of empirical auction research. Anecdotal evidence of collusion in auctions for timber in U.S. national forests has repeatedly been documented (e.g., see U.S. House of Representatives 1977), although few cases have been successfully prosecuted. Early studies focused on differences between bids in oral and sealed-bid auctions as a means of inferring the presence of collusion.

The first study was by Mead (1967). He began by considering how basic industry characteristics affect the merits of oral versus sealed-bid auctions, leaving aside the risk of collusion. He argued that oral bidding is more appropriate when several of the following conditions hold: fixed investment is high, transportation costs are important, sources of raw materials are few, specific qualities are needed, sales are frequent, and financing is limited. He claimed that these considerations explain why oral auctions are used more frequently for timber, whereas sealed-bid auctions are typically preferred for oil and gas. Mead then went on to argue that oral auctions are more susceptible to collusion because they facilitate preclusive bidding. Many years later, Robinson (1985) provided theoretical support for this claim in the context of a single-object auction: assuming that cartel members share the same information, he proved that cartels are stable for oral ascending-bid auctions but not for sealed-bid auctions, in both common value and independent private value auction models. ${ }^{26}$ In the empirical portion of his paper, Mead presented evidence indicating that oral bids had indeed generated lower prices in Forest

\footnotetext{
${ }^{25}$ For example, Milgrom and Weber (1982, p. 1090) stated that "Situations in which bidders collude have received no attention in theoretical [auction] studies."

${ }^{26}$ In a common value model, the object for sale is assumed to have the same value for all bidders, but bidders do not know this value in advance. They differ in terms of their estimates of the object's value. In an independent private values model, the value of the object differs across bidders, and bidders know their own (but not competitors') values.
} 
Service timber sales than sealed bids (the Forest Service uses both bidding procedures), and he concluded that collusion was the reason.

Johnson (1979) contested this conclusion, offering an alternative explanation related to differences between firms. He noted that theoretical results in Vickrey (1961) indicated that oral and sealed bidding should yield similar prices on average when firms are homogeneous and bidding is competitive (no collusion). When firms are heterogeneous, however-for example, when some bidders have a known comparative cost advantage over others-Johnson found that oral bidding can yield lower prices even when bidding is competitive. Further muddying the water, a subsequent theoretical study by Milgrom and Weber (1982) demonstrated that the opposite result-winning prices in oral auctions exceeding those in sealed-bid auctions - can occur in competitive auctions when bidders are symmetric and risk neutral and have "affiliated" values for the object being auctioned. ${ }^{27}$ The upshot is that a simple comparison of winning prices in oral and sealed-bid auctions does not provide a reliable means of detecting collusion.

\subsection{Testing for collusion using econometric methods}

More recent empirical studies on collusion have used increasingly refined statistical techniques. They have examined auctions for not only timber (e.g., Brannman 1996 and Baldwin et al. 1997) but also various other goods and services, including offshore oil leases (Hendricks and Porter 1988), construction contracts (Porter and Zona 1993, Bajari and Ye 2001), and school milk contracts (Porter and Zona 1999, Pesendorfer 2000). Porter and Zona (1993) emphasized that a simple and universal procedure for detecting collusion does not exist and is unlikely to be developed. In large part this is because collusion can take many different forms, including kickbacks (a cartel member pays others to win a specific auction), bid rotation schemes (cartel members alternate who wins), and phantom bidding (cartel members submit fake, losing-bids to create the appearance of competition). In fact, if a universal test for detecting collusion were available, a knowledgeable cartel would have an incentive to devise a bidding strategy, based for example on phantom bids, such that the auction data would appear to have been generated by a competitive process.

\footnotetext{
27 "Roughly, [affiliation] means that a high value of one bidder's estimate makes high values of the others' estimates more likely" (Milgrom and Weber 1982, p. 1096).
} 
The inherent unobservability of key variables is also a problem. The ultimate goal of collusion is to secure high profits, but data on bidders' profits are typically difficult to obtain. State-of-the-art econometric procedures for detecting collusion therefore are linked instead to observable aspects of bidder behavior that are expected to differ in competitive and collusive contexts. These procedures attempt to go beyond the simple detection of patterns that are consistent with collusion, since such patterns could instead merely reflect unobservable characteristics of the bidders or the items being auctioned. In most cases, the procedures involve estimating at least two models, with the structure of one being consistent with bidding being competitive while the structure of the other is consistent with bidding being collusive. The two models are then compared in terms of how well they fit the data.

We review here the procedures employed in three empirical studies: Porter and Zona (1993), which examined auctions for state highway construction contracts on Long Island, and Brannman (1996) and Baldwin et al. (1997), which like Mead (1967) and Johnson (1979) examined U.S. Forest Service timber sales. All three concluded that collusion was occurring. Porter and Zona tested for collusion by analyzing differences in the ranking of competitive and cartel bids using an ordered logit model. With one big exception, they had relatively little information about the firms. The exception was that they knew the composition of the cartel at the start of the sample period. They knew little about the jobs put out for bid aside from the winning bids. Their explanatory variables included a dummy variable for whether a firm is headquartered on Long Island and a "Backlog" variable that gives the dollar value of contracts won and not yet completed by a firm. Other variables are built from "Backlog," such as "Cap," defined as the maximum backlog over the periods considered, or "Util" (= "Backlog"/“Cap"), which accounts for how busy a firm is. Porter and Zona found that the ranking of cartel bids did not coincide with the ranking of costs and thus rejected the null hypothesis of no phantom bids, an outcome which suggests the presence of collusion.

Brannman (1996) focused on the effect of potential competition on winning bids. According to economic theory, potential entrants to an imperfectly competitive market should limit the ability of participating firms to collude. Brannman proposed two measures of potential competition. The first one, called simply potential competition, is a count of the number of firms whose closest mill lies within the boundaries of the market for Forest Service sales. The second one, called expected competition, is the sum of the estimated participation probabilities of firms 
capable of taking part in an auction. He estimated these probabilities using a probit analysis of the link between auction participation and hauling distance.

Brannman included five categories of explanatory variables in his regression models: in addition to the competition variables, Forest Service appraisal components, sale characteristics, bidder characteristics, and product market information. Appraisal components included total appraisal value, selling value, harvesting costs, and manufacturing costs, all per thousand board feet, in addition to the average hauling distance to rival mills and its standard deviation (both were excluded if the expected number of bidders was included). Observed sale characteristics included tract acreage, percentage per-acre material, a dummy for salvage value, road construction costs, a county dummy, and whether the sale was a Small Business Administration set-aside sale. Bidder characteristics had two components: hauling distance to the winner's closest mill, and whether or not a firm is large. Finally, product market information was summarized by average monthly lumber selling prices and contract duration. One difference compared to Porter and Zona is that Brannman did not account for the contracts the firms already held.

Brannman analyzed data from 1977 for both oral and sealed-bid Forest Service auctions. He found that both measures of potential competition were important in explaining winning bids, but not as important as actual competition (ie., the actual number of bidders). He argued that this suggests the presence of collusion. In addition, he found that longer hauling distances were associated with higher winning bids in the sealed-bid auctions. Echoing Mead (1967), he offered preclusive bidding as a likely explanation.

Unlike Brannman, Baldwin et al. (1997) focused exclusively on winning bids in oral auctions. They also based their analysis more directly on the theory of bidder behavior, in an independent private values auction framework. ${ }^{28}$ Brannman had argued that timber auctions fit neither the common value model nor the independent private values model. The key feature of their study was that it used a model presented in Graham and Marshall (1987) to endogenize the effective size of a bidder cartel. The authors had no direct information on whether a cartel existed among Forest Service timber buyers or, if it did, how many firms it contained. They only

\footnotetext{
${ }^{28}$ Vincent (1996) also used an independent private values framework in his analysis of bidding behavior in Suceava.
} 
knew the number of bidders who registered to bid, the highest and second-highest bids, and the identities of the firms who placed those bids. Using assumptions about the distribution of the unobserved private values of the bidders, they developed a maximum likelihood procedure that predicted the size of the cartel that best explained the observed winning bids, controlling for such factors as the volume of timber in a tract, timber quality, logging costs, the terms of the harvest contract, local inventories of timber, and special events that took place during the study period (e.g., natural disasters). They then compared the likelihood statistic from this collusive model to the likelihood statistic from a noncooperative model that included the same variables but no allowance for endogenous cartel formation.

Baldwin et al. analyzed a relatively small sample of 114 Forest Service sales that took place between 1975 and 1981, out of a total of 3,355 sales. They limited the sample so severely in order to ensure that the data were as consistent as possible with the assumptions of the independent private values framework. They estimated five models: a non-cooperative (i.e., competitive) model that treated the sale of each timber tract as a single-unit auction event; a single-unit collusive model; a non-cooperative, multi-unit model that included supply effects resulting from multiple tracts being offered at the same auction (such supply effects could confound the detection of collusion); and two nesting models that combined collusion with the multi-unit model. Their multi-unit model was based on Weber (1983) and Milgrom and Weber (1982), and it was an innovation in the empirical auction literature. They concluded from their econometric results that winning bids were best explained by the models that allowed for collusive behavior.

\section{Econometric analysis of collusion in Romanian timber auctions}

This section presents our econometric analysis of collusion in Romanian timber auctions. Like the mid-1990s study on Romanian timber auctions described in HIID (1996) and Vincent (1996), we analyze data from Suceava, but we also analyzes data from Neamt. The auctions in both cases are oral (ascending-bid) auctions. Neamt was the first forest directorate in Romania to introduce timber auctions as a regular means of selling standing timber to both private and public enterprises, having done so shortly before Suceava. Romanian forestry experts interviewed during June-July 2003 claimed that large enterprises commonly exert market power in Neamt. 
Such concerns were less strongly expressed about auctions in Suceava. This difference makes for a potentially interesting comparison of the two regions.

The biggest difference compared to the mid-1990s study is that we examine the issue of collusion directly. The earlier study focused on determining whether reserve prices reflected differences in the value of tracts put up for bid. In the case of Suceava, we apply the competitive and collusive single-unit models developed by Baldwin et al. (1997). In the case of Neamt, we apply a cruder approach, due to a lack of data on the number of registered bidders for each tract.

The need to apply a cruder approach in Neamt points to another difference compared to the earlier study: available data on tract characteristics were less detailed, even for Suceava. Few data related to the auctions are computerized in either forest directorate. The field team for the earlier study had more time and resources to extract relevant data from written records and enter them into electronic databases. We were able to compile data on the volume of timber in a tract and the type of timber sale (mature, thinning, salvage) for both forest directorates, and several additional tract characteristics for Suceava. This amount of data on tract characteristics is not unsually small compared to the studies on U.S. timber auctions reviewed in section 4 , so at least we can say that we controlled for the effects of tract characteristics on winning bids as well as those studies.

We saw in section 3 that many factors other than collusion and tract characteristics can affect winning bids. We must control for those factors in order to isolate the effects of collusion. The fact that regional timber markets are fairly distinct in Romania is one reason, in addition to differences in data availability, that we analyze Neamt and Suceava separately. Due to the lack of data, for the most part we were unable to develop variables directly related to the other economic and institutional factors. Instead, we used dummy (0-1) variables to control for them. Several of the factors discussed in section 3 can be expected to vary substantially within a forest directorate: number of timber sellers other than the NFA, number of timber buyers, and forest access. To capture the effects of these factors, we included dummy variables for the forest divisions within the directorates. To the extent that corruption is present at different levels in different forest divisions (perhaps absent altogether in some or many), the same dummies will capture its effects. Because many of these factors have changed over time, we also included dummy variables for the dates when the auctions occurred. The time dimension is especially 
important for other factors, such as the AAC and the level of technology in the industry. While the use of dummy variables is fine for the purpose of controlling for potentially confounding factors in order to isolate the effects of collusion, it does not allow us to estimate the impact of those other factors on winning bids. The dummy variables are standing in for several "real" variables simultaneously.

\subsection{Econometric analysis of data from Neamt}

\subsubsection{Background}

Neamt is a forest directorate in northeastern Romania just south of Suceava. The IRIS field team obtained data on all timber tracts sold in the directorate between May 1998 and June 2003. The data set included tracts that sold at negotiated prices in addition to tracts that sold by auction. The former category evidently includes mainly tracts that were originally offered for sale at primary or secondary auctions but failed to sell. The total of number of tracts in the data set was 4,513. Of these, nearly three quarters - 3,355 tracts - sold by auction. Auctions have thus been the main mechanism for selling timber tracts in Neamt.

Table 2 presents basic characteristics of the auction sales during 1999-2003. Note that the data for 2003 cover only the period January-June. Scheduled sales of mature timber and thinnings accounted for most of the sales in terms of both volume and value in all years except 2002, when windstorms resulted in unusually large salvage sales. Scheduled sales were reduced in that year to maintain harvests within the AAC. Mature timber accounted for most of the scheduled sales in every year, especially in value terms.

The bottom panel of the table shows mean winning bids per cubic meter, weighted by timber volumes. Like the values for total revenue, these values are expressed in nominal terms. Inflation thus accounts at least partially for their tendency to increase over time for most sales categories. Within a given year, the pattern of values is generally what one would expect if bids reflect relative timber values: for example, mean winning bids are higher for scheduled sales of mature timber than for scheduled sales of thinnings. Auctions in Neamt at least satisfy this basic criterion of allocative efficiency.

Table 3 presents the same information for timber that sold at negotiated prices. Data were available only through the end of 2002. To begin, note that the volume and especially the 
value of timber sold by negotiation were much less than the corresponding amounts sold by auction. This was true even before October 2001, when NFA Executive Order 6465 banned negotiated sales. Scheduled sales accounted for a smaller proportion of negotiated sales than auction sales in all years except the windstorm year of 2002. Mean negotiated prices were typically much less than mean winning bids from auctions. All of this is consistent with the tracts sold by negotiation being the less desirable ones.

Like most previous studies of timber auctions, we focused our econometric analysis on scheduled sales of mature timber. ${ }^{29}$ Such tracts accounted for only 869 of the tracts in the Neamt data set, but as the amounts in Tables 2 and 3 indicate they accounted for most of the combined value of timber sold by auction and negotiations during 1999-2002. The volume of timber in these tracts ranged from 5 to 8,357 cubic meters, with a mean of 1,765 cubic meters. Winning bids ranged from 55,000 to $1,577,000$ lei per cubic meter, with a mean of 478,237 lei per cubic meter. The ratio of winning bid to reserve price had a mean value of 1.4. Some tracts sold for as much as 4.6 times the reserve price, which suggests that competition among bidders was at times intense.

The amount of data available for explaining the variation in winning bids was limited. This is because very little auction data is computerized in Neamt compared to Suceava. The IRIS field team was able to obtain only the following basic data on each tract:

- Name of forest division (ocolul silvic) where the tract was located

- Volume of timber in the tract

- Type of timber (mature, thinning, salvage)

- Auction date

- Reserve price

- Winning bid

- Name of winning bidder

\footnotetext{
${ }^{29}$ Estimating the amount of harvestable timber and the cost of harvesting are more difficult for salvage sales and thinnings than for sales of mature timber. Consequently, forestry departments and logging companies have a harder time formulating reserve prices and bids, and econometric models of bidding behavior perform more poorly.
} 
The team obtained a small amount of additional information on winning bidders (e.g., addresses), but formatting inconsistencies precluded its use. It did not obtain information on the number of companies that registered to bid on a tract, the number that actually bid, or the bids they placed, other than the winning bid.

Due to these data limitations, our test for collusion is much weaker for Neamt than for Suceava. We explain this test in the next section. We close this section by noting two reasons to believe collusion could be common in Neamt. First, individuals interviewed by the IRIS field team in June and July 2003 reported that it is. They pointed to the fact that just three firmsPetroforest, Romanel Forest Star Tarcau, and New Star-harvest more than half of the total amount of timber sold in the directorate. ${ }^{30}$ These firms are somewhat less dominant in the case of scheduled sales of mature timber, however, accounting for just over a third of the total amount sold by auction.

Second, and perhaps more convincing, winning bids were barely above the reserve price for many tracts. A visual examination of the cumulative distribution of the ratio of winning bid to reserve price revealed a break point at 1.07. Almost exactly half (436 out of 869) of the mature timber tracts sold by auction in Neamt during 1998-2003 had ratios below this value. The mean winning bid for these tracts, 349,780 lei per cubic meter, was significantly different from the mean winning bid for the tracts with a higher ratio, 607,585 lei per cubic meter. ${ }^{31}$ Hence, lower ratios coincided with lower winning bids. They were not a consequence of, say, reserve prices coincidentally being closer to winning bids for more valuable tracts.

\subsubsection{Theoretical model and econometric approach}

Following Baldwin et al. (1997), we define:

$B_{i} \quad$ Winning bid for tract $i$ (lei)

$r_{i} \quad$ Reserve price for tract $i$ (lei)

$v_{i} \quad$ Volume of timber in tract $i$ (cubic meters).

\footnotetext{
${ }^{30}$ These firms also buy timber in neighoring forest directorates.

${ }^{31}$ The means were statistically different regardless of whether we assumed the variances for the two groups were the same or different.
} 
We distinguish the observed winning bid per cubic meter, $B_{i} / v_{i}$, from the winning bidder's valuation of the tract: the bidder's maximum willingness to pay. ${ }^{32}$ We assume that the valuation has a lognormal distribution with mean $\beta^{\prime} \mathbf{z}_{i}$ and variance $\sigma^{2}$, where

\section{$\mathbf{z}_{i} \quad$ Vector of covariates that affect valuation of tract $i$.}

We included as covariates the volume of timber, $v_{i}$, and the volume squared; the natural logarithm of reserve price per cubic meter, $\ln \left(r_{i} / v_{i}\right)$; and dummy variables for forest division and auction date. We included the reserve price in view of the limited data on tract characteristics. As noted in section 2.4, reserve prices are supposed to reflect differences in timber quality and accessibility. The forest division dummies might capture these differences, too. The dummies for auction date control for inflation, market conditions, and differences in auction procedures.

Our testing procedure amounted to evaluating the relative performance of a reference model in which winning bids are assumed to equal bidders' valuations for all tracts to one in which winning bids are assumed to be below valuations for some tracts as a result of collusion. More formally, the null hypothesis is that all winning bids, including those close to reserve prices, equal actual valuations:

$$
\ln \left(B_{i} / v_{i}\right)=\beta^{\prime} \mathbf{z}_{i}+\varepsilon_{i} \forall i .
$$

The alternative hypothesis is that only winning bids that are not close to reserve prices equal actual valuations. Winning bids that are close to reserve prices instead equal lower bounds on actual valuations:

$$
\begin{array}{r}
\ln \left(B_{i} / v_{i}\right)=\beta^{\prime} \mathbf{z}_{i}+\varepsilon_{i} \text { if } B_{i} / r_{i} \geq 1+\delta \\
\ln \left(B_{i} / v_{i}\right) \leq \beta^{\prime} \mathbf{z}_{i}+\varepsilon_{i} \text { if } B_{i} / r_{i}<1+\delta,
\end{array}
$$

where $\delta=0.07$. We test the null by comparing the log likelihood statistic from model (1), which is a simple linear regression model, to the log likelihood statistic from model (2), which is a censored regression model. If the absolute value of the log likelihood statistic from model (2) is smaller, then we reject the null and conclude that collusion could be present. As described in

\footnotetext{
${ }^{32}$ Strictly speaking, the winning bid equals the sum of the actual valuation by the second highest bidder plus the additional increment offered by the highest bidder.
} 
more detail in a moment, our analysis does not rule out explanations other than collusion. If instead we fail to reject the null, then we fail to detect evidence of collusion.

As emphasized, rejection of the null does not necessarily imply that collusion is present. Collusion is a type of unobserved heterogeneity: collusion affects some tracts but not all, and we cannot directly observe which ones it affects. Other tract characteristics have this feature, and they offer competing explanations why model (2) might outperform model (1). One such characteristic is the order in which tracts are auctioned. This is a characteristic that in principle is easily observable, but we have no data on it for the auctions in Neamt. So, from our standpoint as econometricians, it is unobserved. To see how it might generate a set of winning bids that look the set that results from collusion, consider the following simple example. Suppose $n$ bidders attend an auction, and $m$ identical tracts are offered for sale. The number of tracts equals the number of bidders: $n=m$. Suppose that, unknown to other bidders, each bidder demands only a single tract and is willing to pay the same maximum amount for it. The high bids for the first $m-1$ tracts in this auction will equal the maximum willingness to pay (the high bidders' actual valuations), but the high bid for the $m^{\text {th }}$ tract will equal the reserve price, because the sole remaining bidder has no competitors. Model (2) would fit the data from this auction better than model (1), but the reason would be diminished competition for the final tract, not collusion.

\subsection{3. $\underline{\text { Results }}$}

Results are shown for Model (1) in Table 4 and Model (2) in Table 5. The coefficients on the timber volume variables and reserve price are highly significant and similar in magnitude in both tables. The positive sign on timber volume indicates increasing returns to scale in logging, while the negative sign on the squared value of this variable indicates that the scale economies diminish with the volume harvested. The coefficient on reserve price is not significantly different from 1. Given that both this variable and the dependent variable are expressed in logarithmic form, the implication is that winning bid is proportional to reserve price, after controlling for timber volume, forest division, and auction date. The coefficients on many of the dummy variables for forest division and auction date, which are not shown, were also significantly different from zero. 
The absolute value of the log likelihood statistic is substantially smaller in Table 5 than in Table 4. The censored regression model, in which we assume that actual valuations exceed observed winning bids for tracts that sell close to the reserve price, thus fits the data better than the standard linear regression model. We therefore cannot rule out the presence of collusion. We investigated the robustness of this result by re-estimating Model (2) with $\delta$ set equal to values set slightly above and below 0.07: respectively, 0.10, which increased the number of censored observations to 449; and 0.06 , which decreased the number to 435 . The absolute values of the $\log$ likelihood statistics were both larger than the value in Table $5 .^{33}$ The cutoff value of $\delta$ that demarcates tracts that have abnormally low winning bids in view of their timber volumes, reserve prices, locations, and auction dates does indeed appear to be 0.07 .

We estimated just how low the winning bids for these tracts might be by using the model in Table 5 to predict the uncensored values for the tracts. The mean value across the 436 tracts was 669,302 lei per cubic meter, which is much larger than the mean of the actual winning bids for the tracts, 349,780 lei per cubic meter, but not significantly different from the mean winning bid for the 433 uncensored tracts, 607,585 lei per cubic meter.

\subsubsection{Conclusions: Neamt}

We conclude that collusion could be affecting the winning bids in many of the tracts sold in Neamt timber auctions by a large amount. Although our results are strongly suggestive, we cannot rule out other factors as explanations for the unusually low bids for these tracts. Developing a more definitive test of collusion requires a richer data set, such as the one from Suceava. We turn to that analysis now.

\section{2. $\quad$ Econometric analysis of data from Suceava}

Our analysis of Suceava relies on variations of Models 1 and 2 in Baldwin et al. (1997).

\subsection{1. $\underline{\text { Data }}$}

A wealth of information was collected for Suceava by the IRIS team in Romania, including auction, firm, and tract information. Auction data consists of the actual order and amount of bids for each tract. Firm information is mostly location, plus, for four 2002 auctions (March 5, April

\footnotetext{
${ }^{33} 70.2$ and 61.4 , respectively.
} 
20, April 30, and June 19), contract information as well as the maximum authorized annual processing volume of timber. Tract data includes tract location information (such as forestry, production, and management units), volume, area, reserve price, bidding step, various forestry, cutting, and product codes, as well as the high bid and the number of bids.

Table 6 summarizes the number of registered bidders for each tract (by auction date) for tracts sold separately in the 27 different auctions for which we have data. We observe that "large" auctions tend to be followed after a few days by much smaller ones (presumably secondary auctions for tracts which failed to sell at the primary auctions) which appear to be much less competitive, assuming that the mean number of registered bidders per tract gives an indication of the degree of competition to buy the tracts for sale. Over time, it appears that the mean number of bidders has been increasing: the three largest means for the number of bidders are to be found among the four 2002 auctions. It does not imply, however, that auctions have become more competitive, as shown by the mean number of bids per tract in Table 7 . With the exception of the March 5, 2002 auction, the big auctions of 2002 (in April and June) rank second and fourth from the bottom in terms of the mean number of bids per tract. Worse, there is on average only one bid per registered bidder for these two auctions.

For this report, we focus on the April 20, 2002 and June 19, 2002 auctions. The main reason for this choice is the availability of contract information, which also tells us about supply constraints for the firms participating in these auctions. This information is critical for our methodology, recognizing that what could be interpreted as the result of collusive activities may in fact be due to changes in the supply of timber. After eliminating records for non-mature timber and for tracts sold in groups or tracts with only one registered bidder, as well as incomplete or clearly erroneous records (e.g., a few tracts had a negative area) and tracts with less than 100 cubic meters of timber (an unusually small amount), we are left with 615 observations: 387 for the April 20, 2002 auction and 228 for the June 19, 2002 auction.

Table 8 presents a summary of some of the key variables for the tracts we consider. Unfortunately, we have little direct information about the cost of harvesting timber for each tract. Although location may play a role (see Table 9 for forest divisions in Suceava), we need to rely on variables such as area (ceteris paribus, it may be costlier to harvest timber on a larger area), or 
cod_produs (see Table 10). Unfortunately, there is no variation of harvesting system in our sample (see Table 11).

Ideally, following Baldwin et al. (1996), we would like to have information about the inventory of the auction participants. A higher inventory would likely lessen the urgency to acquire new timber and therefore should lead to lower timber prices. Since this information is unavailable, we construct a crude index of the supply situation by dividing the volume of timber under contract for the auction participants (at the beginning of each auction) by their annual authorized timber volume. This information is stored in the variable CapRatio in Table 8 .

For the 615 tracts of mature timber we analyze, the volume of timber ranged from 100 to 11420 cubic meters (mean: $1521 \mathrm{~m}^{3}$ ); tract area varied between 0.05 ha and 512.7 ha, with a mean of 71.5 ha. The corresponding high bids per $\mathrm{m}^{3}$ ranged from a low of 173,000 lei to a high of $1,009,000$ lei, with a mean of 480,944 lei ( 1 USD $=33,933.50$ lei). The mean number of bids per tract was 8.54 , with a minimum of 1 and a maximum of 46 .

\subsubsection{Theoretical models and econometric approach}

Throughout this analysis, we assume that the hypotheses of the standard independent private values (IPV) model hold (see Milgrom and Weber 1982). The IPV framework seems to make sense here because mills often have different production costs and holdings of uncut timber. In addition, a number of theoretical results are available in this framework and not in others.

Key assumptions of the IPV model include:

- Bidders are risk neutral.

- All bidders are equally well informed about the quality and quantity of timber on any given tract. This is one reason why we are restricting our analysis to mature timber sales, which are almost all second-growth; second-growth timber is typically more homogenous than old-growth timber.

- Bidders also have the same information about future potential price movements, although in practice large firms may have an information advantage if they are involved in export markets or have better government connections.

Although some of these assumptions are not very satisfactory, they are necessary to implement our theoretical models. 
As a starting point, we consider two models. One of their main roles is to explain low winning bids. One potential reason is the presence of collusion, but this is by no means the only possible explanation. Demand for timber could also be depressed by a number of factors, which we try to capture through covariates. These factors could be linked for example to timber quality or to supply constraints. We try to capture some of the latter through the variable CapRatio.

As in the analysis of Neamt auctions, we define:

$B_{i} \quad$ Winning bid for tract $i$ (lei);

$r_{i} \quad$ Reserve price for tract $i$ (lei);

$v_{i} \quad$ Volume of timber in tract $i$ (cubic meters).

In addition, we define

$n_{i} \quad$ Number of registered bidders for tract $i$.

We also suppose that observed winning bid per cubic meter, $\ln \left(B_{i} / v_{i}\right)$ is normally distributed with mean $\beta^{\prime} \mathbf{z}_{\mathbf{i}}$ and variance $\sigma^{2}$ where $\mathbf{z}_{\mathbf{i}}$ is a vector of covariates. This is a convenient assumption also used in Baldwin et al. (1997). Covariates considered include:

- Volume of timber on a tract for sale (cubic meters). Indeed, it has been suggested that there are increasing returns with volume of a tract.

- Square of the volume of timber, for non-linear effects.

- Area of a tract, in hectares. We supposed that the area of a tract could impact logging costs.

- Dummy variables for the NFA ID codes for forest divisions, to capture unobserved specific circumstances in different forest divisions (see Table 9).

- Type of timber sale (cod_produs; see Table 10).

- CapRatio, which equals the volume of firms partaking in an auction divided by their annual authorized volume of timber.

Unfortunately, we had no data on actual logging costs or timber quality. A first step of our model selection process is to select what covariates we want to use in our two models. Preliminary regression helped us make a first selection among these covariates. We found that dummy variables for forest divisions were all insignificant, so we did not include them in the remainder of this analysis. Likewise, timber type (cod_produs) was not significant at 5\%. By 
contrast, all the other covariates are strongly significant and have the expected signs: positive for volume (more timber increases the value of a tract), negative for volume ${ }^{2}$ (there may be diminishing scale economies with the volume harvested, as for Neamt), negative for area (less timber per unit area decreases value), and strongly negative for CapRatio (as firms are close to their annual maximum harvest, they have less of an incentive to purchase rights to new timber). Table 12 presents a regression without the forest division variables.

As mentioned in the previous section, we observe only the number of bidders willing to pay at least the reserve price. We should therefore model the value distribution as a distribution censored from below by the reservation price, which varies from tract to tract. In our dataset of 615 observations, 94 observations are within 1.055 of the reservation price. In order to take advantage of the information contained in these observations, we censor them by discarding their actual value but we retain that they are within $5.5 \%$ of the reserve price.

We are now ready to present our 2 models. Model 1 assumes non-cooperative behavior in an English auction with unit supply. It follows that the winner will pay the second highest valuation overall. Baldwin et al. (1997) show that the corresponding likelihood function is

$$
L(\beta, \sigma ; D)=\left[\prod_{i \in I_{a}} \frac{v_{i}}{\sigma b_{i}} f_{2}\left(u_{i} \mid r_{i}, n_{i}\right)\right]\left[\prod_{i \in I_{b}} F_{2}\left(y_{i} \mid r_{i}, n_{i}\right)\right],
$$

where:

$\beta$ is the unknown vector of coefficients of the covariates $\mathbf{z}_{\mathbf{i}}$;

$\sigma^{2}$ is the unknown variance of the distribution of $\ln \left(B_{i} / v_{i}\right)$;

$D$ is our data set;

$I_{a}$ is the set of uncensored high bids;

$I_{b}$ is the set of censored high bids;

$u_{i}=\frac{\ln \left(b_{i} / v_{i}\right)-\beta^{\prime} \mathbf{z}_{\mathbf{i}}}{\sigma}, s_{i}=\frac{\ln \left(r_{i} / v_{i}\right)-\beta^{\prime} \mathbf{z}_{\mathbf{i}}}{\sigma}, y_{i}=\frac{\ln \left(1.07 r_{i} / v_{i}\right)-\beta^{\prime} \mathbf{z}_{\mathbf{i}}}{\sigma}$.

$n_{i}$ is the numbers of bidders for auction $i$;

$f_{2}\left(u i \mid r_{i}, n_{i}\right)$ and $F_{2}\left(u i \mid r_{i}, n_{i}\right)$ are respectively the density and the distributions of the $2^{\text {nd }}$ order statistics of $n$ independent draws from a standardized normal distribution truncated from below by $r_{i}$. 
More generally, if $f_{\alpha}\left(u i \mid r_{i}, n_{i}\right)$ and $F_{\alpha}\left(u i \mid r_{i}, n_{i}\right)$ are respectively the density and the distributions of the $\alpha^{\text {th }}$ order statistics of $n$ independent draws, from a standardized normal distribution truncated from below by $r_{i}$, then

$$
\left.f_{\alpha}(u \mid r, n)=\frac{n !}{(n-\alpha) !(\alpha-1) ! 1-\Phi(u)} \frac{\phi(u)}{1(u)-\Phi(s)}\right)^{\alpha}\left(\frac{1-\Phi(u)-\Phi(s)}{1-\Phi(s)}\right)^{n},
$$

and

$$
F_{\alpha}(u \mid r, n)=\sum_{j=0}^{\alpha-1} \frac{n !}{(n-j) ! j !}\left(\frac{1-\Phi(u)}{\Phi(u)-\Phi(s)}\right)^{j}\left(\frac{\Phi(u)-\Phi(s)}{1-\Phi(s)}\right)^{n},
$$

where $\phi(\cdot)$ and $\Phi(\cdot)$ are respectively the standard normal density and cumulative distribution functions.

Model 2 is a model of collusion in an English auction with unit supply. If a coalition contains $k$ bidders with the $k$-highest values and not the $k+1^{\text {st }}$ one, then the coalition will pay the latter. Using the same notation as for Model 1, the likelihood function for Model 2 is

$$
L(\beta, \gamma, \sigma ; D)=\left[\prod_{i \in I_{a}} \frac{v_{i}}{\sigma b_{i}} h_{c}\left(u_{i} \mid r_{i}, n_{i}\right)\right]\left[\prod_{i \in I_{b}} H_{c}\left(y_{i} \mid r_{i}, n_{i}\right)\right],
$$

where:

$$
h_{c}\left(u_{i} \mid r_{i}, n_{i}\right)=\sum_{\alpha=2}^{n} q_{i \alpha}^{c} f_{\alpha}\left(u_{i} \mid r_{i}, n_{i}\right), H_{c}\left(y_{i} \mid r_{i}, n_{i}\right)=p_{i}^{c}+\sum_{\alpha=2}^{n} q_{i \alpha}^{c} F_{\alpha}\left(y_{i} \mid r_{i}, n_{i}\right) \text {, }
$$

and $q_{i 2}^{c}=1-p_{i}^{2}, q_{i \alpha}^{c}=p_{i}^{\alpha-1}\left(1-p_{i}\right)$ for $\alpha=3 \rightarrow \mathrm{n}_{\mathrm{i}}$. In addition, the probability that a bidder joins a coalition at auction $i$ is given by

$$
p_{i}=\frac{e^{\gamma}}{1+e^{\gamma}}
$$

In the above, $\gamma$ is an unknown parameter that needs to be estimated from the data.

Models 1 and 2 were estimated using a program written in GAUSS after managing the data in STATA. It should be emphasized that the log likelihood functions for Models 1 and 2 are difficult to estimate because they admit local maxima. After unsuccessfully trying to find their maximum using the Gauss procedure optimum, we switched to a simulated annealing algorithm 
which is much more robust and much more reliable for maximizing functions of several variables (see Corana et al., 1987).

\subsection{3. $\quad$ Results}

Results of our maximum likelihood estimations are summarized in Tables 13A and 13B. Our best estimates for both models do not include volume squared, which no longer appears to be significant. For Model 1, we see that all variables are significant (at 5\% at least) and they have the expected sign (see the discussion above). For Model 2, we obtain very interesting results: volume is now insignificant, and most importantly $p_{i}$, the estimate of the probability that a bidder joins a coalition at auction $i$ is now quite high and very significant: inserting $\gamma=1.2358$ from Table $13 \mathrm{~B}$ in (8) leads to $p_{i}=0.775$. The signs of the other coefficients are as expected. In addition, we find that the value of the logarithm of the likelihood function for Model 2 is much higher than for Model 1; a likelihood ratio test is significant at 1\%. Note, however, that caution is necessary when interpreting this test because the probability of collusion is at the boundary of its permissible domain under the null hypothesis; we know from Andrews (2001) for example, that this situation causes difficulties similar to unidentification so standard asymptotics may fail. An approach similar to the one used by Khalaf, Saphores, and Bilodeau (2003) in a different context may be used to address this problem.

These results suggest nevertheless that the collusive model with unit supply (Model 2) clearly outperforms our non-cooperative model with unit supply (Model 1) for the auctions that took place in Suceava on April 20, 2002 and on June 19, 2002.

\subsubsection{Conclusions: Suceava}

These results suggest the presence of collusion during the 2002 forestry auctions in Suceava. They are in line with anecdotal comments gathered by the IRIS field research team during the collection of the data used in this report. It is important to emphasize that these findings are not very surprising, given results from studies that found evidence of collusion in forestry auctions in the United States for example (see Baldwin et al., 1996).

However, these results are still preliminary. In future work, the lognormal assumption should be checked; more elaborate auction models, especially Models 3-5 in Baldwin et al. 
(1987), should be evaluated; and a better parameterization of the probability that a firm will join a coalition should be attempted.

\subsection{Conclusions}

This paper has attempted to detect collusion in Romanian forestry auctions for two forest directorates, Neamt and Suceava, using two different econometric methodologies to reflect data availability. Neamt was the first forest directorate in Romania to introduce timber auctions. Unfortunately, relatively little data was available electronically. For example, the research team could not get electronic records of important tract characteristics such as the composition of timber by size class and species group, which contributes to the value of a tract, or the distance of a tract to the nearest forestry road, which contributes to harvesting costs. A lack of resources also precluded the collection of information about mill location and the density of forestry roads. In addition, detailed bidding information including the number of bidders for each tract was unavailable. Some of these limitations also existed for Suceava.

The data analyzed for Neamt is a subset of scheduled sales of mature timber between 1999 and 2002. Our testing procedure contrasted the maximum likelihood of a simple regression model in which winning bids were assumed to equal bidders' valuations for all tracts, to a censored regression model that isolated tracts where the winning bid was within $7 \%$ of the reservation price. We found that the censored regression model fits the data better than the standard linear regression model, so we cannot rule out the presence of collusion, although collusion is not the only possible explanation for this better fit.

Our analysis of timber auctions in Suceava, which focused on 2002 auctions, provides stronger evidence of collusion. Detailed bidding information, including the order and the size of each bid, was available, and this allowed us to use more powerful econometric models that also start to account for supply effects. In our analysis, we contrasted two models in an English auction with unit supply: Model 1 assumed competitive behavior, while Model 2 assumed that a subset of bidders colludes to lower the winning bid. Our results show that the collusive model (Model 2) strongly outperforms the competitive model (Model 1) for the auctions analyzed.

While these models are not yet entirely satisfactory — partly because auction theory is still lagging behind actual auction design and practice but also because of potential econometric complications - these results suggest the presence of collusion in Romanian forestry auctions. 
These findings reinforce anecdotal evidence gathered by the IRIS field team in Neamt, where just three firms harvest more than half of the total amount of timber sold in that directorate and are alleged to engage in collusive bidding.

Collusion in auctions is by no means unique to Romania or to developing economies. As discussed in section 4, collusion has also been detected in U.S. Forest Service auctions and in other U.S. markets where auctions are used, including highway construction and milk contracts for schools. Auctions offer a very useful mechanism for allocating contracts, however, and they are likely to become increasingly popular as developing economies try to increase their competitiveness. As in other markets, it is necessary to ensure transparency and the respect of ground-rules to maintain competition and confidence in the economic institutions. In this regard, it is reassuring that increasingly sophisticated and powerful econometric methods are becoming available to detect instances where these rules are violated and collusion occurs.

For Romania, this study suggests that efforts should be made to systematically collect and make available data to enable ongoing analyses of forestry auctions. In addition to information on individual bids for each tract (bid level, bid order, and bidder identity), these data should include basic firm information (such as mill location and capabilities) and tract information (tree species and their corresponding volume as well as basic parameters that determine harvesting costs). Even with enhanced electronic availability of data, we doubt that "real-time" analysis of Romanian timber auctions will be possible. Instead, we envision a situation in which analysts, perhaps local academics working under contract for the Ministry or some other appropriate government agency, would annually apply the sorts of methods presented in this report to data from auctions during the past year. They would prepare a sort of "Timber Auction Competitiveness Report." The aim would be identify forest directorates where collusion is more likely to be occurring. The government could then use this information to conduct targeted investigations and implement measures to reduce collusion and its consequences.

What types of anti-collusion measures are available to the government? Discussion of this point in HIID (1996, p. 2) remains relevant:

Governments can take several actions to reduce the risks and consequences of imperfect competition in stumpage auctions. One is to adopt and enforce anti-collusion laws. Reportedly, such a law will go into effect in Romania on January 1, 1997. A second is to minimize (but not necessarily eliminate) the requirements that bidders must satisfy to participate in auctions. ... A third action is to coordinate the dates of auctions with the 
forestry calendar, to ensure that more timber is offered for sale when demand (and thus potential competition) is high. Romsilva [i.e., the NFA] faces rules [related to the AAC allocation] that reportedly violate this principle. ... A fourth action ... is to employ starting prices (reserve prices) as a means of preventing eventual winning prices from being too far below fair market values.

Klemperer (2004), in a recent and influential book on auction design, emphasizes low entry barriers and economically meaningful reserve prices as "what really matter" in fighting collusion. ${ }^{34}$ The most obvious entry barrier in Romanian timber auctions is the prohibition against foreign participation. The government could consider relaxing this rule in forest directorates where there is evidence of collusion among domestic companies. Publication of forest management plans might also lead to a more rational spatial distribution of mills with regard to available timber supplies, reducing the number of instances where only a few mills are located in close proximity to areas where many tracts are scheduled for auction.

The HIID (1996) report was motivated by the government's interest in developing improved procedures for setting reserve prices, in part to combat collusion. It concluded that the government could make better use of winning prices in past auctions to set reserve prices in upcoming auctions. This method is termed transactions analysis. It amounts to setting the reserve prices for new tracts equal to winning prices for comparable tracts that sold in past auctions, minus a margin to reduce the risk of overstating the value of a tract and causing it to go unsold. Statistical techniques are used to calculate comparable prices. This method is used routinely in timber auctions in western countries. A disadvantage is that if collusion is common, then basing reserve prices on winning prices from past auctions will simply perpetuate the downward pressure of collusion on winning prices. A solution to this problem is to use techniques like the ones presented in this paper to identify tracts where bidding appears to have been affected by collusion and remove them from the database used to set reserve prices.

A second method is residual value analysis, which considers the difference between log prices and logging costs. This method is also commonly used, but it relies on information that is

\footnotetext{
${ }^{34}$ A fine (but not unimportant) point is whether governments should reveal their reserve prices to bidders. Policies vary in recently created timber auction systems. In Cameroon, as in Romania, reserve prices are made public before auctions. In Ghana, however, they are revealed only if none of the received bids exceeds them. Revealing reserve prices to bidders certainly makes it easier for colluding bidders to determine how low they can go and still be awarded a tract.
} 
less directly observable by the government (i.e., information about logging costs). Largely for this reason, the HIID report concluded that transactions analysis was the more suitable method for setting reserve prices in Romanian timber auctions. This conclusion is even more likely to be correct today, given the decade of additional data on winning bids and tract characteristics that can in principle be used to establish the market value of tracts yet to be auctioned. Implementing transactions analysis will be hindered in Romania, however, until a more comprehensive and consistent effort is made to computerize auction data across forest directorates. 
Table 1. Scheduled sales of mature timber at Romanian timber auctions held during January-July, 2003

\begin{tabular}{|c|c|c|c|c|c|c|c|c|c|c|c|c|c|}
\hline \multirow[b]{2}{*}{ Region } & \multirow{2}{*}{$\begin{array}{c}\text { Forest } \\
\text { directorate }\end{array}$} & \multicolumn{2}{|c|}{ All species } & \multicolumn{2}{|c|}{ Coniferous } & \multicolumn{2}{|c|}{ Beech } & \multicolumn{2}{|c|}{ Oaks } & \multicolumn{2}{|c|}{$\begin{array}{c}\text { Mixed } \\
\text { hardwoods }\end{array}$} & \multicolumn{2}{|c|}{$\begin{array}{c}\text { Mixed } \\
\text { softwoods }\end{array}$} \\
\hline & & $\begin{array}{c}\text { Volume } \\
\left(m^{3}\right)^{*}\end{array}$ & \begin{tabular}{|c|} 
Winning \\
bid \\
$\left(l e i / m^{3}\right) * *$ \\
\end{tabular} & $\begin{array}{c}\text { Volume } \\
\left(m^{3}\right)^{*}\end{array}$ & $\begin{array}{c}\text { Winning } \\
\text { bid } \\
\left(l e i / \mathrm{m}^{3^{* *}}\right)\end{array}$ & $\begin{array}{c}\text { Volume } \\
\left(m^{3}\right)^{*}\end{array}$ & \begin{tabular}{|c|} 
Winning \\
bid \\
$\left(\mathrm{lei} / \mathrm{m}^{3}\right) * *$ \\
\end{tabular} & $\begin{array}{c}\text { Volume } \\
\left(\mathrm{m}^{3}\right)^{*}\end{array}$ & $\begin{array}{c}\text { Winning } \\
\text { bid } \\
\left(l e i / m^{3}\right)^{* *}\end{array}$ & $\begin{array}{c}\text { Volume } \\
\left(\mathrm{m}^{3}\right)^{*}\end{array}$ & $\begin{array}{c}\text { Winning } \\
\text { bid } \\
\left(l e i / m^{3^{* *}}\right)\end{array}$ & $\begin{array}{c}\text { Volume } \\
\left(m^{3}\right)^{*}\end{array}$ & $\begin{array}{c}\text { Winning } \\
\text { bid } \\
\left(l e i / m^{3}\right)^{* *}\end{array}$ \\
\hline \multirow[t]{6}{*}{ Central } & Alba & 96,154 & 597,356 & 44,171 & 615,862 & 39,730 & 602,580 & 5,076 & 658,134 & 6,610 & 410,646 & 567 & 422,227 \\
\hline & Brasov & 58,961 & 542,455 & 8,540 & 660,718 & 44,720 & 541,285 & 1,797 & 444,857 & 3,904 & 342,088 & & \\
\hline & Cluj & 58,600 & 575,598 & 19,745 & 746,163 & 29,447 & 538,809 & 1,985 & 699,235 & 7,423 & 234,780 & & \\
\hline & Hunedoara & 180,195 & 580,241 & 47,481 & 600,101 & 120,996 & 585,281 & 6,806 & 531,170 & 4,912 & 332,106 & & \\
\hline & Salaj & 28,391 & 974,933 & 2 & 281,000 & 16,210 & $1,044,64$ & 9,021 & $1,035,507$ & 2,629 & 425,968 & 529 & 536,554 \\
\hline & Sibiu & 70,491 & 705,101 & 34,609 & 666,902 & 20,584 & 781,282 & 7,908 & 839,604 & 7,085 & 532,877 & 305 & 411,536 \\
\hline \multirow[t]{6}{*}{ Danube } & Constanta & 30,990 & 466,872 & & & & & & & 3,989 & 570,920 & 27,001 & 451,501 \\
\hline & Dolj & 83,248 & 474,746 & & & & & 14,013 & 568,509 & 16,536 & 437,329 & 52,699 & 461,555 \\
\hline & Ialomita & 185,739 & 511,557 & & & & & & & 9,783 & 841,972 & 175,956 & 493,186 \\
\hline & Mehedinti & 106,420 & 451,671 & & & 77,656 & 458,008 & 9,227 & 524,224 & 5,986 & 366,136 & 13,551 & 403,738 \\
\hline & Olt & 23,663 & 522,829 & & & & & 6,690 & 742,113 & 3,803 & 558,041 & 13,170 & 401,270 \\
\hline & Tulcea & 47,587 & 448,046 & & & & & 1,217 & 438,000 & 3,444 & 340,000 & 42,926 & 457,000 \\
\hline \multirow[t]{4}{*}{ East } & Botosani & 25,878 & 944,329 & & & 11,852 & $1,203,84$ & 2,071 & $1,498,226$ & 3,048 & 750,752 & 8,907 & 536,458 \\
\hline & Iasi & 98,859 & 908,310 & 373 & 667,716 & 19,858 & 916,193 & 14,840 & $1,579,692$ & 26,090 & 848,010 & 37,698 & 683,977 \\
\hline & Vaslui & 42,914 & 681,868 & & & 13,073 & 817,807 & 5,021 & $1,021,284$ & 8,952 & 456,716 & 15,868 & 589,496 \\
\hline & Vrancea & 150,768 & 892,515 & 10,467 & 695,421 & 94,349 & 968,199 & 7,801 & $1,954,600$ & 12,489 & 654,621 & 25,662 & 487,556 \\
\hline \multirow[t]{7}{*}{ Northeast } & Bacau & 361,430 & 638,880 & 76,876 & 529,606 & 263,705 & 667,666 & 2,334 & 786,530 & 3,675 & 565,255 & 14,840 & 688,440 \\
\hline & Covasna & 55,490 & 661,540 & 20,537 & 701,115 & 32,527 & 603,174 & 2,426 & $1,109,069$ & & & & \\
\hline & Harghita & 84,185 & 680,674 & 77,590 & 697,738 & 6,595 & 479,912 & & & & & & \\
\hline & Maramures & 231,376 & 663,994 & 68,345 & 591,492 & 153,813 & 672,022 & 8,110 & $1,151,127$ & 1,108 & 456,085 & & \\
\hline & Mures & 187,336 & 648,292 & 121,641 & 675,714 & 49,382 & 596,845 & 5,571 & 797,703 & 9,170 & 494,216 & 1,572 & 511,760 \\
\hline & Neamt & 466,192 & 660,448 & 333,592 & 651,406 & 109,721 & 674,213 & 4,736 & $1,168,285$ & 10,515 & 691,121 & 7,628 & 500,297 \\
\hline & Suceava & $1,444,07$ & 555,539 & $1,399,58$ & 552,225 & 44,489 & 659,824 & & & & & & 83,820 \\
\hline
\end{tabular}


Table 1. Scheduled sales of mature timber (continued)

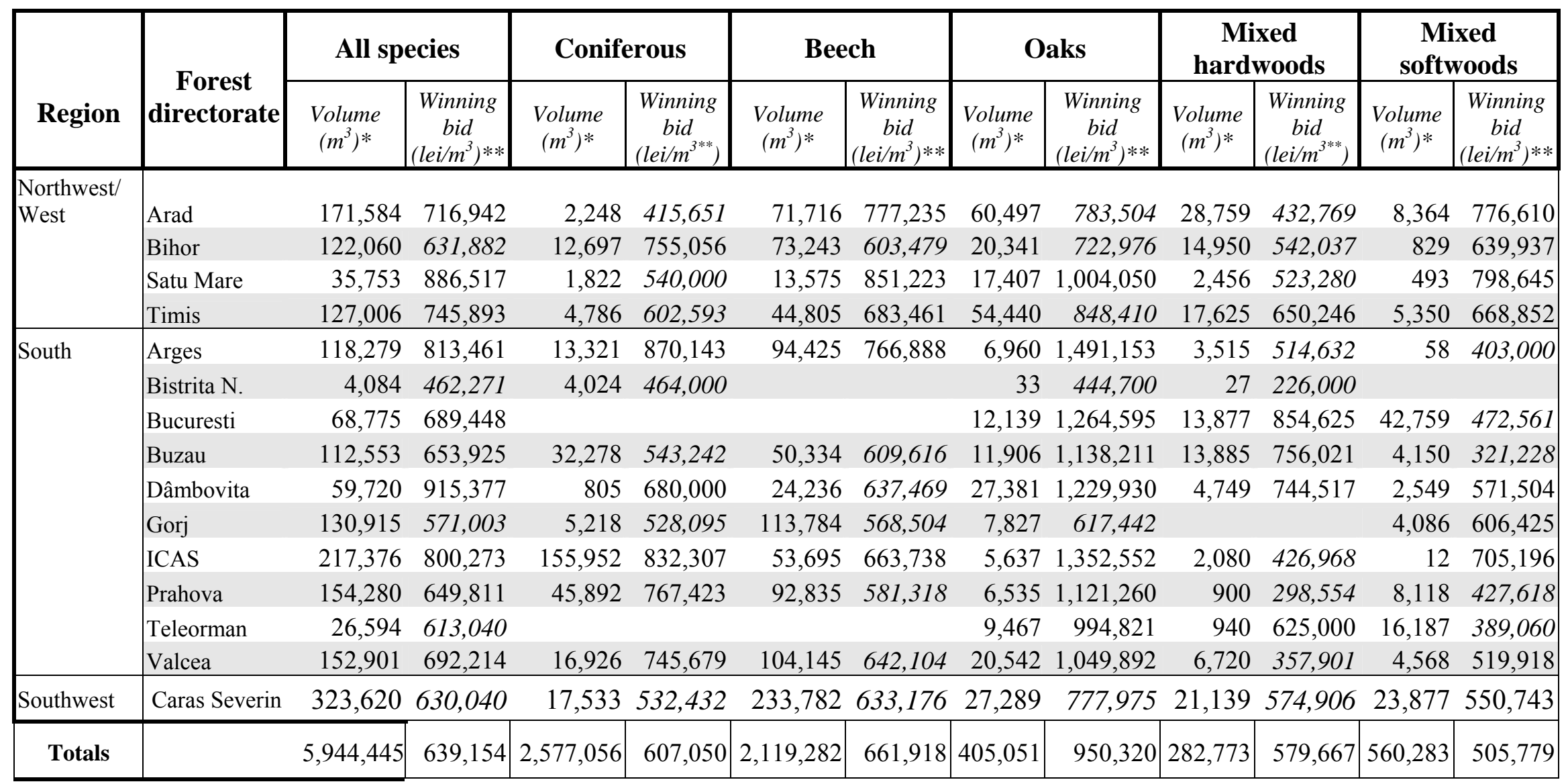

Source: Romanian National Forestry Utility

Notes: *Volumes are totals for the 7-month period.

**Winning bids are weighted-average means. Winning bids in italics are ones that are below the national mean. 
Table 2. Summary data on timber sold by auction in Neamt Forest Directorate

\begin{tabular}{|c|c|c|c|c|c|c|}
\hline \multirow{2}{*}{ Characteristic } & \multirow{2}{*}{ Type of sale } & \multicolumn{5}{|c|}{ Year } \\
\hline & & 1999 & 2000 & 2001 & 2002 & $2003^{*}$ \\
\hline \multirow{7}{*}{$\begin{array}{l}\text { Total volume } \\
\left(\text { thousand } \mathrm{m}^{3} \text { ) }\right.\end{array}$} & Scheduled: mature timber & 263.6 & 476.3 & 477.9 & 157.0 & 100.3 \\
\hline & Scheduled: thinning & 73.8 & 74.4 & 119.4 & 69.2 & 93.1 \\
\hline & Salvage: mature timber & 140.3 & 86.1 & 64.2 & 459.9 & 63.6 \\
\hline & Salvage: immature timber & 7.0 & 0.8 & 2.7 & 9.9 & 2.7 \\
\hline & Salvage: diseased timber & 0.8 & 6.9 & 22.3 & 1.6 & 0.0 \\
\hline & Total & 485.5 & 644.5 & 686.7 & 697.7 & 259.7 \\
\hline & $\%$ Scheduled & $69 \%$ & $85 \%$ & $87 \%$ & $32 \%$ & $74 \%$ \\
\hline \multirow{7}{*}{$\begin{array}{l}\text { Total revenue } \\
\text { (billion lei) }\end{array}$} & Scheduled: mature timber & 85.6 & 280.8 & 272.7 & 93.1 & 72.7 \\
\hline & Scheduled: thinning & 8.2 & 14.6 & 26.5 & 13.9 & 29.6 \\
\hline & Salvage: mature timber & 34.1 & 20.9 & 31.4 & 242.5 & 38.0 \\
\hline & Salvage: immature timber & 1.8 & 0.1 & 1.2 & 2.5 & 1.1 \\
\hline & Salvage: diseased timber & 0.1 & 2.6 & 6.3 & 0.5 & 0.0 \\
\hline & Total & 129.8 & 319.0 & 338.2 & 352.4 & 141.3 \\
\hline & $\%$ Scheduled & $72 \%$ & $93 \%$ & $89 \%$ & $30 \%$ & $72 \%$ \\
\hline \multirow{5}{*}{$\begin{array}{l}\text { Mean winning bid } \\
\text { (thousand lei per } \mathrm{m}^{3} \text { ) }\end{array}$} & Scheduled: mature timber & 325 & 590 & 571 & 593 & 724 \\
\hline & Scheduled: thinning & 110 & 196 & 222 & 201 & 318 \\
\hline & Salvage: mature timber & 243 & 243 & 489 & 527 & 597 \\
\hline & Salvage: immature timber & 261 & 120 & 420 & 249 & 402 \\
\hline & Salvage: diseased timber & 119 & 369 & 283 & 313 & - \\
\hline
\end{tabular}

Source: Romanian National Forestry Utility, Neamt branch.

* For 2003, January-June only. 
Table 3. Summary data on timber sold by negotiation in Neamt Forest Directorate

\begin{tabular}{|c|c|c|c|c|c|}
\hline \multirow{2}{*}{ Characteristic } & \multirow{2}{*}{ Type of sale } & \multicolumn{4}{|c|}{ Year } \\
\hline & & 1999 & 2000 & 2001 & 2002 \\
\hline \multirow{7}{*}{ 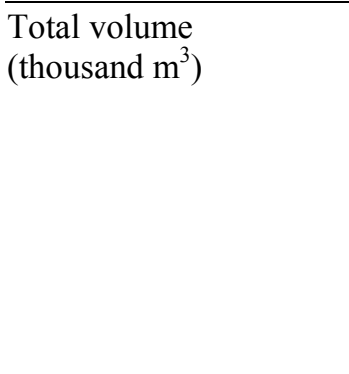 } & Scheduled: mature timber & 22.3 & 48.0 & 0.9 & 29.1 \\
\hline & Scheduled: thinning & 39.4 & 40.5 & 6.5 & 0.0 \\
\hline & Salvage: mature timber & 49.8 & 39.2 & 2.5 & 14.5 \\
\hline & Salvage: immature timber & 3.7 & 1.7 & 0.1 & 1.3 \\
\hline & Salvage: diseased timber & 0.1 & 3.2 & 0.0 & 0.0 \\
\hline & Total & 115.3 & 132.5 & 9.9 & 45.0 \\
\hline & $\%$ Scheduled & $54 \%$ & $67 \%$ & $74 \%$ & $65 \%$ \\
\hline \multirow{7}{*}{$\begin{array}{l}\text { Total revenue } \\
\text { (billion lei) }\end{array}$} & Scheduled: mature timber & 3.7 & 11.7 & 0.4 & 12.7 \\
\hline & Scheduled: thinning & 3.0 & 3.2 & 0.7 & 0.0 \\
\hline & Salvage: mature timber & 5.9 & 6.8 & 0.6 & 7.1 \\
\hline & Salvage: immature timber & 0.3 & 0.2 & 0.0 & 0.3 \\
\hline & Salvage: diseased timber & 0.0 & 0.4 & 0.0 & 0.0 \\
\hline & Total & 12.9 & 22.4 & 1.8 & 20.1 \\
\hline & $\%$ Scheduled & $52 \%$ & $67 \%$ & $65 \%$ & $63 \%$ \\
\hline \multirow{5}{*}{$\begin{array}{l}\text { Mean price } \\
\text { (thousand lei per } \mathrm{m}^{3} \text { ) }\end{array}$} & Scheduled: mature timber & 164 & 243 & 468 & 437 \\
\hline & Scheduled: thinning & 77 & 80 & 114 & - \\
\hline & Salvage: mature timber & 118 & 174 & 244 & 492 \\
\hline & Salvage: immature timber & 83 & 122 & 173 & 204 \\
\hline & Salvage: diseased timber & 75 & 137 & - & 205 \\
\hline
\end{tabular}

Source: Romanian National Forestry Utility, Neamt branch. 


\section{Table 4. Estimation results for model (1), Neamt.}

Generalized linear model

Optimization : ML: Newton-Raphson

Log likelihood $=-122.9747963$
No. of obs $=869$

Residual df $=809$

AIC $=.4211158$

$$
\ln \left(B_{i} / v_{i}\right) \mid \quad \text { Coef. } \quad \text { Std. Err. } \quad z \quad \quad \mathrm{P}>|\mathrm{z}| \quad \text { [95\% Conf. Interval] }
$$

\begin{tabular}{c|cccccc}
$\ln \left(r_{i} / v_{i}\right)$ & 1.06333 & .0491702 & 21.63 & 0.000 & .9669586 & 1.159702 \\
$v_{i}$ & .0000641 & .0000232 & 2.77 & 0.006 & .0000187 & .0001095 \\
$v_{i}^{2}$ & $-9.79 \mathrm{e}-09$ & $4.08 \mathrm{e}-09$ & -2.40 & 0.016 & $-1.78 \mathrm{e}-08$ & $-1.80 \mathrm{e}-09$ \\
Constant & -.2070782 & .5604832 & -0.37 & 0.712 & -1.305605 & .8914486
\end{tabular}

Note: Model also includes 23 dummy variables for forest division (dummy for Bicaz is omitted) and 34 dummy variables for auction date (dummy for May 14, 1998 auction is omitted).

Table 5. Estimation results for model (2), Neamt.

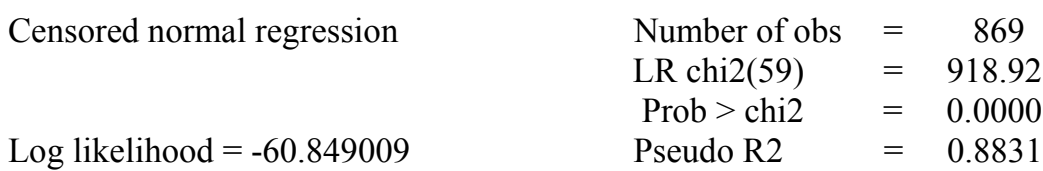

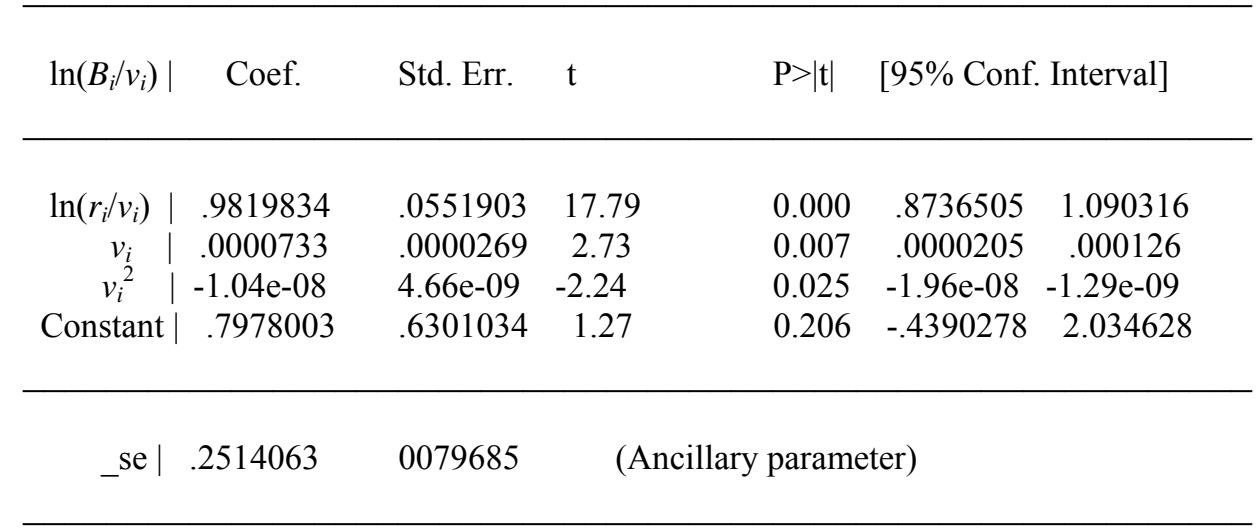

Obs. summary: 433 uncensored observations

436 right-censored observations

Note: Model also includes 23 dummy variables for forest division (dummy for Bicaz is omitted) and 34 dummy variables for auction date (dummy for May 14, 1998 auction is omitted). 
Table 6. Statistics on the number of registered bidders for tract by auction date

\begin{tabular}{|c|c|c|c|c|c|}
\hline $\begin{array}{l}\text { Auction } \\
\text { Date }\end{array}$ & $\begin{array}{l}\text { \# of } \\
\text { Tracts }\end{array}$ & Mean & $\begin{array}{l}\text { Standard } \\
\text { Deviation }\end{array}$ & Min & Max \\
\hline 09 Feb 00 & 230 & 3.31 & 1.92 & 1 & 10 \\
\hline 16 Feb 00 & 34 & 1.26 & 0.62 & 1 & 3 \\
\hline 15 Mar 00 & 75 & 2.12 & 1.05 & 1 & 5 \\
\hline 22 Mar 00 & 28 & 1.25 & 0.52 & 1 & 3 \\
\hline 07 Apr 00 & 147 & 3.01 & 1.76 & 1 & 8 \\
\hline 21 Apr 00 & 41 & 1.32 & 0.65 & 1 & 3 \\
\hline 14 Jun 00 & 106 & 2.21 & 1.04 & 1 & 6 \\
\hline 16 Jun 00 & 25 & 1.16 & 0.37 & 1 & 2 \\
\hline 25 Aug 00 & 156 & 3.62 & 1.77 & 1 & 10 \\
\hline 30 Aug 00 & 17 & 1.53 & 0.51 & 1 & 2 \\
\hline 08 Sep 00 & 170 & 5.28 & 2.64 & 1 & 12 \\
\hline 13 Sep 00 & 16 & 1.38 & 0.72 & 1 & 3 \\
\hline 06 Dec 00 & 83 & 6.01 & 2.53 & 1 & 12 \\
\hline 09 Feb 01 & 283 & 4.88 & 2.65 & 1 & 12 \\
\hline 14 Feb 01 & 22 & 1.14 & 0.35 & 1 & 2 \\
\hline 02 May 01 & 364 & 6.52 & 3.46 & 1 & 18 \\
\hline 09 May 01 & 19 & 2.00 & 0.75 & 1 & 3 \\
\hline 29 Jun 01 & 355 & 7.62 & 3.64 & 1 & 18 \\
\hline 04 Jul 01 & 13 & 3.00 & 0.41 & 2 & 4 \\
\hline 31 Aug 01 & 284 & 4.80 & 2.35 & 1 & 12 \\
\hline 04 Sep 01 & 17 & 2.24 & 0.90 & 1 & 4 \\
\hline 31 Oct 01 & 417 & 6.89 & 3.21 & 1 & 21 \\
\hline 07 Nov 01 & 12 & 2.42 & 0.67 & 2 & 4 \\
\hline 05 Mar 02 & 228 & 8.73 & 4.12 & 1 & 20 \\
\hline 20 Apr 02 & 450 & 8.48 & 4.06 & 1 & 28 \\
\hline 30 Apr 02 & 6 & 2.50 & 1.38 & 1 & 4 \\
\hline 19 Jun 02 & 371 & 9.76 & 5.30 & 1 & 26 \\
\hline All & 3969 & 6.06 & 4.07 & 1 & 28 \\
\hline
\end{tabular}

Notes. These statistics are based on the "Ofert" file, which includes only tracts sold separately. For 397 tracts, there was a single registered bidder. 
Table 7. Statistics on the number of bids by auction date

\begin{tabular}{|c|c|c|c|c|c|}
\hline $\begin{array}{l}\text { Auction } \\
\text { Date }\end{array}$ & $\begin{array}{l}\text { \# of } \\
\text { Tracts }\end{array}$ & Mean & $\begin{array}{l}\text { Standard } \\
\text { Deviation }\end{array}$ & Min & Max \\
\hline 20000209 & 190 & 8.34 & 10.19 & 1 & 49 \\
\hline 20000216 & 8 & 2.13 & 2.48 & 1 & 8 \\
\hline 20000315 & 56 & 10.34 & 12.97 & 2 & 51 \\
\hline 20000322 & 6 & 2.33 & 816 & 2 & 4 \\
\hline 20000407 & 110 & 13.24 & 13.22 & 1 & 54 \\
\hline 20000421 & 9 & 8.89 & 9.56 & 1 & 29 \\
\hline 20000614 & 83 & 5.70 & 12.90 & 1 & 100 \\
\hline 20000616 & 4 & 1 & 0 & 1 & 1 \\
\hline 20000825 & 140 & 8.91 & 10.67 & 1 & 47 \\
\hline 20000830 & 7 & 3.71 & 7.18 & 1 & 20 \\
\hline 20000908 & 158 & 10.70 & 12.03 & 1 & 73 \\
\hline 20000913 & 4 & 2.25 & 0.96 & 1 & 3 \\
\hline 20001206 & 81 & 11.99 & 10.20 & 1 & 37 \\
\hline 20010209 & 262 & 10.53 & 13.64 & 1 & 56 \\
\hline 20010214 & 6 & 5.33 & 9.67 & 1 & 25 \\
\hline 20010502 & 342 & 13.20 & 17.68 & 1 & 95 \\
\hline 20010509 & 20 & 1 & 0 & 1 & 1 \\
\hline 20010629 & 348 & 14.36 & 17.46 & 1 & 75 \\
\hline 20010704 & 16 & 1 & 0 & 1 & 1 \\
\hline 20010831 & 263 & 9.38 & 12.01 & 1 & 73 \\
\hline 20010904 & 15 & 2.53 & 1.19 & 2 & 6 \\
\hline 20011031 & 409 & 15.89 & 14.32 & 1 & 69 \\
\hline 20011107 & 12 & 2.58 & 1.00 & 2 & 5 \\
\hline 20020305 & 231 & 22.22 & 16.80 & 1 & 102 \\
\hline 20020420 & 641 & 8.87 & 9.38 & 1 & 70 \\
\hline 20020430 & 8 & 3.63 & 4.31 & 1 & 13 \\
\hline 20020619 & 790 & 8.04 & 7.48 & 1 & 48 \\
\hline 20020625 & 58 & 3.26 & 3.88 & 2 & 19 \\
\hline All & 4279 & 10.96 & 13.07 & 1 & 102 \\
\hline
\end{tabular}

Notes. These statistics are based on the "auction_data_2000-2001-2002" file. It includes all tracts. 
Table 8. Summary Statistics for the Auction Data Analyzed

Auction Date: April 20, 2002.

\begin{tabular}{llllll}
\hline \hline Variable & Obs & Mean & Std. Dev. & Min & Max \\
\hline Volume & 387 & 1470.106 & 1233.288 & 108 & 8678 \\
Area & 387 & 61.68269 & 65.85765 & 0.6 & 512.7 \\
up & 387 & 3.45478 & 2.00773 & 0 & 10 \\
cu & 387 & 9.18863 & 6.496557 & 1 & 21 \\
cod_produs & 387 & 5.656331 & 0.4755471 & 5 & 6 \\
cod_taiere & 387 & 35 & 0 & 35 & 35 \\
ResPrice & 387 & 341257.5 & 41397.82 & 220221 & 436790 \\
WinBid & 387 & 504423.8 & 149951.1 & 232000 & 1009000 \\
Nbids & 387 & 9.095607 & 8.064742 & 1 & 46 \\
CapRatio & 387 & 0.1892 & 0 & 0.1892 & 0.1892 \\
\hline
\end{tabular}

Auction Date: June 19, 2002.

\begin{tabular}{llllll}
\hline \hline Variable & Obs & Mean & Std. Dev. & Min & Max \\
\hline Volume & 228 & 1607.307 & 1415.558 & 100 & 11420 \\
Area & 228 & 88.09772 & 84.61378 & 0.05 & 423.2 \\
up & 228 & 3.175439 & 1.566419 & 0 & 8 \\
cu & 228 & 14.59211 & 4.258739 & 8 & 21 \\
cod_produs & 228 & 5.671053 & 0.4708646 & 5 & 6 \\
cod_taiere & 228 & 35 & 0 & 35 & 35 \\
ResPrice & 228 & 313829.7 & 47660.49 & 156107 & 415518 \\
WinBid & 228 & 441092.1 & 124478.6 & 173000 & 809000 \\
Nbids & 228 & 7.600877 & 6.529054 & 1 & 32 \\
CapRatio & 228 & 0.2625 & 0 & 0.2625 & 0.2625 \\
\hline \hline
\end{tabular}

Notes. Volume is in cubic meters. Area is in ha. Cod_produs 5 or 6 indicate felling in large areas affected by windthrows. Cod_taiere is the NFA ID code for a harvesting system; "cu" is the NFA ID code for a forest division (ocolul silvic); "up" is the production unit where tracts are located. ResPrice is the reservation price in lei $/ \mathrm{m}^{3}$. WinBid is the winning bid in lei $/ \mathrm{m}^{3}$. Nbids is the number of bids per tract. CapRatio is the ratio of timber under contract divided by the annual authorized amount of timber for all firms who registered in an auction. 
Table 9. NFA ID codes and names for forest divisions (ocolul silvic, cu)

\begin{tabular}{|c|c|c|c|c|}
\hline $\begin{array}{c}\text { Forestry Unit } \\
\text { Code }\end{array}$ & COD & Forestry Unit & $\begin{array}{c}\text { Chief of Forestry } \\
\text { Unit }\end{array}$ & Foresty Unit Sub-units \\
\hline 1 & BROSTENI & OS Brosteni & ing.Palade Radu & Ocolul Silvic Brosteni \\
\hline 2 & CRUCEA & OS Crucea & ing.Palade Petru & Ocolul Silvic Crucea \\
\hline 3 & DORNACAN & OS Dorna Candreni & ing.Boghean Petru & Ocolul Silvic Dorna Candreni \\
\hline 4 & COSNA & OS Cosna & ing.Birladeanu B. & Ocolul Silvic Cosna \\
\hline 5 & VATRADOR & OS Vatra Dornei & ing.Carcea Maria & Ocolul Silvic Vatra Dornei \\
\hline 6 & IACOBENI & OS Iacobeni & ing.Fodor Mihai & Ocolul Silvic Iacobeni \\
\hline 7 & CIRLIBAB & OS Cfrlibaba & ing.Turcanu C. & Ocolul Silvic Cfrlibaba \\
\hline 8 & BREAZA & OS Breaza & ing.Coman Constantin & Ocolul Silvic Breaza \\
\hline 9 & POJORITA & OS Pojor $f$ ta & ing.Solovastru V. & Ocolul Silvic Pojor $f$ ta \\
\hline 10 & VAMA & OS Vama & ing.Malis Vasile & Ocolul Silvic Vama \\
\hline 11 & MOLDOVIT & OS Moldovita & ing.Selaru Vasile & Ocolul Silvic Moldovita \\
\hline 12 & FRASIN & OS Frasin & ing.Gingolia Dan & Ocolul Silvic Frasin \\
\hline 13 & STULPICA & OS Stulpicani & ing.Miros Radu & Ocolul Silvic Stulpicani \\
\hline 15 & SOLCA & OS Solca & ing.Cotoar $†$ Petru & Ocolul Silvic Solca \\
\hline 16 & MARGINEA & OS Marginea & ing.Totoescu Adrian & Ocolul Silvic Marginea \\
\hline 17 & PUTNA & OS Putna & ing.Chidovet Stelian & Ocolul Silvic Putna \\
\hline 18 & FALCAU & OS Falc $\dagger u$ & ing.Mutescu Ioan & Ocolul Silvic Falc†u \\
\hline 19 & BRODINA & OS Brodina & ing.Hlodec Vasile & Ocolul Silvic Brodina \\
\hline 20 & MALIN & OS M†lini & ing.Vod† Petru & Ocolul Silvic M†lini \\
\hline 21 & RISCA & OS R $f$ sca & ing.Stefan Dan & Ocolul Silvic $\mathrm{R} f$ sca \\
\hline 22 & FALTICEN & OS F†lticeni & ing.Negura Gheorghe & Ocolul Silvic F†lticeni \\
\hline
\end{tabular}

Note. "Cu" is the NFA ID code for a forest division (ocolul silvic).

Table 10. Types of Timber Sales (Cod_produs)

\begin{tabular}{cl}
\hline Code & \multicolumn{1}{c}{ Translation } \\
\hline 1 & Salvage I (not in areas affected by windthrows I) \\
2 & Salvage I ((not in areas affected by windthrows II) \\
3 & Felling in areas affected by windthrows (I) \\
4 & Felling in areas affected by windthrows (II) \\
5 & Felling in large areas affected by windthrows (I) \\
6 & Felling in large areas affected by windthrows (II) \\
7 & Thinning \\
8 & Sanitary Felling \\
\hline
\end{tabular}


Table 11. NFA nomenclature for harvesting systems (Cod_taiere)

\begin{tabular}{|c|c|c|c|}
\hline $\begin{array}{l}\text { Cutting } \\
\text { Code }\end{array}$ & $\begin{array}{l}\text { Cutting } \\
\text { Type }\end{array}$ & $\begin{array}{l}\text { Cutting } \\
\text { Group }\end{array}$ & $\begin{array}{l}\text { Translation } \\
\text { Cutting Group }\end{array}$ \\
\hline 1 & rase pe parchete mici & 1 & Clearcuts \\
\hline 2 & rase in benzi & 1 & Clearcuts in stripes \\
\hline 3 & succesive in margine de masiv & 2 & Uniform shelterwood system felling - stand edge \\
\hline 4 & succesive 1 & 2 & Uniform shelterwood system felling \\
\hline 5 & succesive 2 & 2 & Uniform shelterwood system felling \\
\hline 6 & succesive 3 & 2 & Uniform shelterwood system felling \\
\hline 7 & succesive 4 & 2 & Uniform shelterwood system felling \\
\hline 8 & succesive definitive & 2 & Uniform shelterwood system felling (final felling) \\
\hline 9 & $\begin{array}{l}\text { progresive in margine de } \\
\text { masiv }\end{array}$ & 3 & $\begin{array}{l}\text { Group/non-uniform shelterwood system felling (Progressive) - } \\
\text { stand edge }\end{array}$ \\
\hline 10 & progresive 1 & 3 & $\begin{array}{l}\text { Group/non-uniform shelterwood system felling (Progressive) - } \\
\text { final felling }\end{array}$ \\
\hline 11 & progresive 2 & 3 & Group/non-uniform shelterwood system felling (Progressive) \\
\hline 12 & progresive 3 & 3 & Group/non-uniform shelterwood system felling (Progressive) \\
\hline 13 & progresive 4 & 3 & Group/non-uniform shelterwood system felling (Progressive) \\
\hline 14 & progresive -racordare & 3 & Group/non-uniform shelterwood system felling (Progressive) \\
\hline 15 & cvasigradinarite 1 & 4 & Group selection system felling \\
\hline 16 & cvasigradinarite 2 & 4 & Group selection system felling \\
\hline 17 & cvasigradinarite 3 & 4 & Group selection system felling \\
\hline 18 & cvasigradinarite 4 & 4 & Group selection system felling \\
\hline 19 & cvasigradinarite 5 & 4 & Group selection system felling \\
\hline 20 & cvasigradinarite 6 & 4 & Group selection system felling \\
\hline 21 & cvasigradinarite definitive & 4 & Group selection system felling - final felling \\
\hline 22 & gradinarite & 4 & Selection system and conversion to selection system felling \\
\hline 23 & transformare spre gradinarit & 4 & Selection system and conversion to selection system felling \\
\hline 24 & in cadrul lucr.de conservare & 5 & Conservation felling \\
\hline 25 & de cring simplu & 6 & Coppice system felling \\
\hline 26 & de cring -cazanire & 6 & Coppice system felling including removal of stump \\
\hline 27 & de cring -scaun & 6 & Coppice system felling (1-1.5m above ground) \\
\hline 28 & de refacere & 7 & Clearcuts for forest type rehabilitation \\
\hline 29 & de substituire & 7 & Clearcuts for forest type substitution \\
\hline 30 & de ingrijire & 8 & Thinning \\
\hline 31 & igienizarea padurii & 9 & Sanitary felling \\
\hline 32 & t. de transformare in pasuni & 10 & Clearcuts in afforested pastures \\
\hline 33 & t. de rarire in pasuni impad. & 10 & Thinning in afforested pastures \\
\hline 34 & t. in aliniamente & 11 & Clearcuts of tree alignements \\
\hline 35 & t. de accidentale I & 12 & Salvage \\
\hline 36 & t. de accidentale II & 12 & Salvage \\
\hline
\end{tabular}

Notes. Cod_taiere is the NFA ID code for a harvesting system. 
Table 12. Preliminary Regression for Auctions held on April 20, 2002 \& June 19, 2002

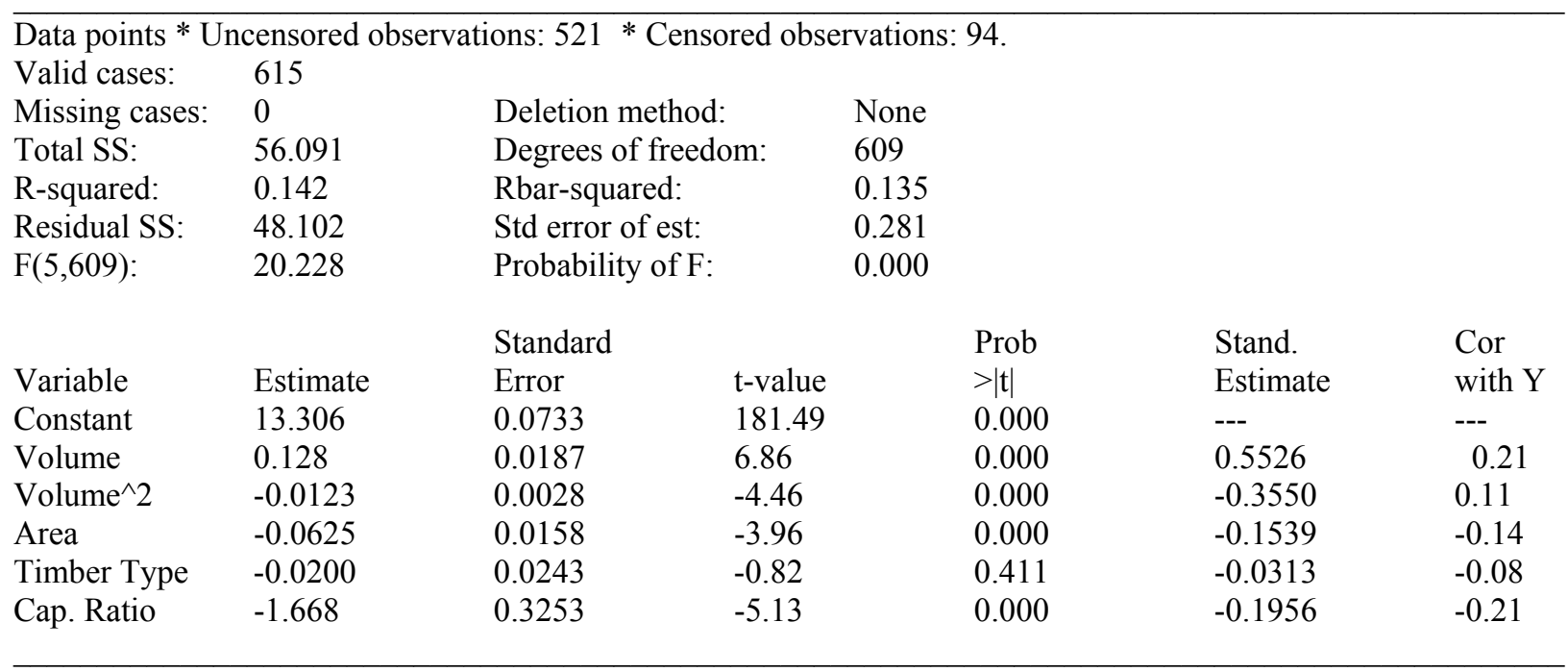

Notes. The dependent variable is $\ln \left(\right.$ Winning Bid per $\mathrm{m}^{3}$ ) if the winning bid is more than 1.055 times the reservation price per $\mathrm{m}^{3}$; otherwise, it is censored and replaced by $1.055 *$ reservation price per $\mathrm{m}^{3}$. Volume is in $\mathrm{m}^{3} / 1000$. Volume ${ }^{2}$ is in $\left(\mathrm{m}^{3} / 1000\right)^{2}$. Area is in ha / 100. Only tracts with 100 cubic meters or more of timber are analyzed here. Timber Type is a dummy variable for Cod_produs $=5$. CapRatio is the ratio of timber under contract divided by the annual authorized amount of timber for all firms who registered in an auction. Estimates above are used as starting values for estimating Models 1 and 2. 
Table 13A: Model 1: Parameters, Standard Errors, and MLE

\begin{tabular}{lll}
\hline Parameter & Value & St. error \\
\hline Sigma & 0.696715 & 0.025895 \\
Constant & 11.595983 & 0.430996 \\
Volume & 0.011545 & 0.006752 \\
Area & -0.044298 & 0.009011 \\
Cap. Ratio & -5.636284 & 1.146541
\end{tabular}

Log Maximum likelihood $=-7590.72$

Table 13B: Model 2: Parameters, Standard Errors, and MLE

\begin{tabular}{lll}
\hline Parameter & Value & St. error \\
\hline Sigma & 0.658505 & 0.085333 \\
Constant & 13.943434 & 0.280554 \\
Volume & -0.000753 & 0.020999 \\
Area & -0.162008 & 0.080215 \\
Cap. Ratio & -9.784077 & 2.307241 \\
Gamma & 1.235801 & 0.060740 \\
\end{tabular}

Log Maximum likelihood $=-6901.56$

Notes. The dependent variable is $\ln \left(\right.$ Winning Bid per $\mathrm{m}^{3}$ ) if the winning bid is more than 1.055 times the reservation price per $\mathrm{m}^{3}$; otherwise, it is censored and replaced by $1.055 *$ reservation price per $\mathrm{m}^{3}$. Volume is in $\mathrm{m}^{3} / 1000$. Volume ${ }^{2}$ is in $\left(\mathrm{m}^{3} / 1000\right)^{2}$. Area is in ha / 100. Only tracts with 100 cubic meters or more of timber are analyzed here. CapRatio is the ratio of timber under contract divided by the annual authorized amount of timber for all firms who registered in an auction. The dependent is assumed to be normally distributed and sigma is an estimate of its standard deviation. 


\section{References}

Andrews, D.W.K., 2001, "Testing when a parameter is on the boundary of the maintained hypothesis," Econometrica 69: 683-734

Baldwin, L.H., R.C. Marshall, and J.-F. Richard, 1997. "Bidder Collusion at Forest Service Timber Sales", Journal of Political Economy 105(4): 657-699

Bajari, P. and G. Summers, 2002. "Detecting Collusion in Procurement Auctions", Antitrust Law Journal 70: 143-170.

Bajari, P. and L. Ye, 2001. "Deciding between Competition and Collusion", Working Paper, Stanford University (version May 18).

Brannman, L.E., 1996. "Potential Competition and Possible Collusion in Forest Service Timber Auction”, Economic Inquiry 34: 730-745.

Corana, A., M. Marchesi, C. Martini, And S. Ridella, 1987. "Minimizing Multimodal Functions of Continuous Variables with the 'Simulated Annealing' Algorithm," ACM Transactions on Mathematical Software, 13 (3 - September): 262-280.

Graham, D.A. and R.C. Marshall, 1987. "Collusive Bidder Behavior at Single-Object SecondPrice and English Auctions”, Journal of Political Economy 95 (December): 1217-1239.

Hendricks, K. and R.H. Porter, 1988. "An Empirical Study of an Auction with Asymmetric Information," American Economic Review 78: 865-883.

Hendricks, K. and R.H. Porter, 1989. "Collusion in Auctions," Annales d'Economie et de Statistique 15/16 (July-December): 217-230.

Harvard Institute for International Development, 1996. "Final Report: Transactions Analysis of Stumpage Auctions in Suceava, Romania." Report prepared for Central and Eastern European Environmental Economics and Policy Project and submitted to USAID.

Johnson, R.N., 1979. “Oral Auction versus Sealed Bids: An Empirical Investigation”, Natural Resources Journal 19 (April): 315-335.

Khalaf, L., J.-D. Saphores, and J.-F. Bilodeau, 2003. "Simulation-based exact jump tests in models with conditional heteroskedasticity," Journal of Economic Dynamics and Control 28 (2003) 531-553.

Klemperer, P., 2004. Auctions: Theory and Practice. Princeton University Press, Princeton, New Jersey.

Mattey, Joe P., 1990. The Timber Bubble that Burst: Government Policy and the Bailout of 1984. Oxford University Press, New York.

Mead, W.J., 1967. "Natural Resource Disposal Policy - Oral Auction versus Sealed Bids", Natural Resources Journal 7 (April): 194-224.

Milgrom, P.R. and R.J. Weber, 1982. "A Theory of Auctions with Competitive Bidding." Econometrica 50 (September): 1089-1122.

Pesendorfer, M., 2000. "A Study of Collusion in First-Price Auctions", Review of Economic Studies 67: 381-411. 
Porter, R.H. and J.D. Zona, 1993. "Detection of Bid Riggins in Procurement Auctions", Journal of Political Economy 101: 518-538.

Porter, R.H. and J.D. Zona, 1999. "Ohio School Milk Markets: An Analysis of Bidding”, Rand Journal of Economics 30(2): 263-288.

Robinson, M.S. 1985. "Collusion and the Choice of Auction," Rand Journal of Economics 16(1): 141-145.

Saphores, J.-D., L. Khalaf, and D. Pelletier, 2002, "On jumps and ARCH effects in natural resource prices - An application to Pacific Northwest stumpage prices," American Journal of Agricultural Economics 84 (2): 387-400.

U.S. House of Representatives, House Committee on Agriculture, 1977. Timber Sales Methods and Related Practices, Ninety-Fifth Congress (Washington, D.C.: U.S. Government Printing Office).

Vickrey, W., 1961."Counterspeculation, Auctions, and Competitive Sealed Tenders", Journal of Finance 16 (March): 8-37.

Vincent, J.R., 1996. "Natural Resource Market Evolution in a Transition Economy." Paper presented in Environmental Economics Seminar, Kennedy School of Government and Department of Economics, Harvard University.

Waggener, Thomas R., 1969. "Some Economic Implications of Sustained Yield as a Forest Regulation Model." University of Washington, Institute of Forest Resources, Contribution No. 6. Seattle.

Weber, R.J., 1983. "Multiple-Object Auctions." In Auctions, Bidding, and Contracting: Uses and Theory, edited by R. Engelbrecht-Wiggans, M. Shubik, and R.M. Stark (New York: New York University Press). 


\section{Appendix: List of Individuals Interviewed (June-August, 2003)}

\begin{tabular}{|l|l|l|}
\hline Date & Organization, place & Person (name and/or position) \\
\hline 19.06 & ICAS, Bucharest & $\begin{array}{l}\text { Mr Gheorghe Parnuta, general director } \\
\text { Mr Ovidiu Badea and Mrs Simona Dragoi, forest } \\
\text { management studies department }\end{array}$ \\
\hline 25.06 & $\begin{array}{l}\text { Ministry of Agriculture, } \\
\text { Forests, Waters, and } \\
\text { Environment, Bucharest }\end{array}$ & $\begin{array}{l}\text { Mr Adrian Popa, chief, department of management of private } \\
\text { forests }\end{array}$ \\
\hline 25.06 & same) & Mrs Carmen Enescu, jurist \\
\hline 1.07 & same) & $\begin{array}{l}\text { Mr Gheorghe Marinescu, chief of forest fund department } \\
\text { Mrs Maria Moise }\end{array}$ \\
\hline 1.07 & $\begin{array}{l}\text { NFA headquarters, } \\
\text { Bucharest }\end{array}$ & $\begin{array}{l}\text { Mrs Simona Dabulean } \\
\text { Mrs Celsea }\end{array}$ \\
\hline 7.07 & $\begin{array}{l}\text { ITRSC (forest } \\
\text { inspectorate), Suceava }\end{array}$ & $\begin{array}{l}\text { Mr Melinte, chief } \\
\text { Mr Radu Sbarna } \\
\text { Mr Mihai Mihetiu } \\
\text { Mr Sorin Popescu }\end{array}$ \\
\hline 8.07 & $\begin{array}{l}\text { NFA headquarters, } \\
\text { Bucharest }\end{array}$ & Mr Corduneanu, director, forest fund \\
\hline 8.07 & $\begin{array}{l}\text { Department of External } \\
\text { Trade, Bucharest }\end{array}$ & Mr Gica Draganescu, director \\
\hline 17.07 & $\begin{array}{l}\text { NFA Forest Directorate, } \\
\text { Ialomita }\end{array}$ & $\begin{array}{l}\text { Mr Ioan Tatoi, director } \\
\text { Mr Ioan Lorin, economist } \\
\text { Mr Cozan, forest fund department }\end{array}$ \\
\hline 18.07 & $\begin{array}{l}\text { NFA Forest Directorate, } \\
\text { Timisoara }\end{array}$ & $\begin{array}{l}\text { Mr Francisc Toth, director } \\
\text { Mr Baban, chief, forest fund department }\end{array}$ \\
\hline 25.07 & $\begin{array}{l}\text { NFA Forest Directorate, } \\
\text { Suceava }\end{array}$ & $\begin{array}{l}\text { Mr Marius Burciu } \\
\text { Mr Iulian Stasiuc }\end{array}$ \\
\hline 27.07 & $\begin{array}{l}\text { Chamber of Trade and } \\
\text { Industry }\end{array}$ & Vice-president \\
\hline 21.08 & $\begin{array}{l}\text { Petroforest, } \\
\text { Piatra Neamt }\end{array}$ & $\begin{array}{l}\text { Romanel, } \\
\text { Piatra Neamt }\end{array}$ \\
\hline 21.08 & $\begin{array}{l}\text { New Star, } \\
\text { Piatra Neamt }\end{array}$ & Mr Viorel Mestecaneanu, executive manager \\
\hline
\end{tabular}

